\title{
"CSR leads to economic growth or not": an evidence-based study to link corporate social responsibility (CSR) activities of the Indian banking sector with economic growth of India
}

\author{
Eliza Sharma ${ }^{1}\left[\right.$ M. Sathish ${ }^{1}$ \\ Received: 22 December 2020 / Accepted: 2 February 2022 / Published online: 1 March 2022 \\ (c) The Author(s), under exclusive licence to Springer Nature B.V. 2022
}

\begin{abstract}
The study aims to measure the link between CSR and economic growth. This study investigates whether CSR expenses shown by the banks are contributing to the sustainability of an emerging economy like India. For this study, CSR spending of 21 commercial banks, on nine development areas of the Indian economy, the human development index of India, and its indicators along with the growth rate of GDP of India and state-wise GDP for the year 2014-2015 to 2017-2018 have been taken as secondary data. The research techniques used are the case analysis method, correlation, and descriptive analysis. The study highlights that CSR activities are more of a myth and a far-reaching possibility in developing nations like India, where most institutions are engrossed in such activities to gain laurels and secure investors from the globe.
\end{abstract}

Keywords Corporate social responsibility · Banks · India - Economic growth · Environment sustainability $\cdot$ CSR marketing

\section{Introduction}

Corporate social responsibility (CSR) has become widespread use within and beyond the corporate world. It is a concept that depicts companies not only focused on the sole purpose of generating profit; instead, they also have an ethical duty to give back to the society that helps them flourish (Garriga \& Meie, 2004; Sharma, 2011). When companies invest in CSR activities, they receive appreciation and rewards from the national and international business communities and

\footnotetext{
Eliza Sharma

Eliza.phd1986@gmail.com

M. Sathish

sathish.mahendiran@sibm.edu.in

1 Symbiosis International (Deemed) University, Bengaluru, India
} 
forums because these investments directly contribute towards economic growth (Sharma, 2011). More importantly, all the multinational firms eagerly contribute to the welfare of their fellow citizens and other developing countries. In this context, financial institutions, especially banks, have been working hard to build the brand image as community-based institutions, resulting in better profitability, sustainability, and long-term success (Bihari \& Pradhan, 2011; Deegan, 2000; Yuan et al., 2011). Researchers have observed evidence of a positive relationship between the firm's CSR project investments and the performance of financial institutions, especially in the banking sector (Mansoor, 2016).

Various sectors are contributing towards economic development by investing in CSR projects. Still, the banking sector is the only sector that supports projects like community development, education and skill development, environmental sustainability, healthcare, rural development projects, sports, and welfare, especially in women empowerment which is directly contributing towards to economic growth (Ramasamy \& Ting, 2004; Mansoor, 2016; Siegel \& Vitaliano, 2007). Many researchers proved the link between CSR and bank performance (Chen et al., 2018; Gond \& Herrbach, 2006; Swarnpali \& Le, 2018; Ting, 2020). The interesting observation is that the specific link between banking sector growth and economic growth is proved by many researchers (Margolis \& Walsch, 2003; Navarro Espigares \& Lopez, 2006; Skare \& Golja, 2014), so the Indian banking sector is considered for this study. If the banks invest seriously in CSR activities, it should reflect on their performance, so it proved that the spending on these activities impacts their performance, but are these investments making a tangible impact on the economic indexes? The direct link between CSR and a country's economic growth was not measured even though regulatory bodies have made it compulsory for the companies and banks to invest $2 \%$ of their net profits for CSR. Earlier the CSR activities performed by banks were out of their own choice or will and the availability of funds, but now it is mandatory (Khandelwal \& Swarna, 2014). Hence, the banks should invest a certain amount in CSR activities every year. The disclosure principle made it more difficult for the banks, as they need to disclose various details like when the CSR activities happened, where they happened, and how much they have spent on CSR activities in a year. The multiple indexes like income index, education index, employment rate, and healthcare index are considered indirect measures for any developing country's economic growth (Howell et al., 2003; McGrath, 2011). The banking industry spend CSR investments in projects related to rural development projects, education, skill development, and accessible healthcare, which have a direct impact on the various indexes of economic growth (Perrini et al., 2011; Wagner, 2010).

The motive of regulatory agencies was clear while forming the CSR Act, 2014, to make all the profit-making corporates give back to society in the form of CSR some part of their profits or help the government develop the economy (Khandelwal \& Swarna, 2014). As the funds or resources available to the government are not adequate to grow the economy rapidly to achieve high growth rates, corporates should also contribute towards this goal of sustainable development (Maxwell et al., 2000; Mcwilliams \& Siegel, 2001). 
Banking is the only industry investing a considerable amount of money in highvolume projects compared to other sectors; besides, these CSR projects are highly correlated towards the country's economic development (Guiral, 2012; Sharma, 2011). These CSR activities include education, community development, women and child development, the healthcare sector, and livelihood projects, but the nation's growth is too slow. But still, these investments did not make a significant impact on any index that uses the measure for economic growth. The government is struggling to provide better healthcare services to its citizens, and the literacy rate is far too less for India. The unemployment rate among youth is around $23 \%$, which depicts its miserable side (Acharya, 2006; Juscius, 2007; Macmillan et al., 2003; Netar, 2017; Szczuka, 2015). India has not placed in the top 50 nations in the HDI ranking. There is no evidence of improving the economic index even after investing reasonably in these projects. Are these investments funded, or are only the numbers shown by the banks? This dilemma leads our research study, and this paper investigates these arguments.

From 2014 onwards, all the listed banks and companies started contributing $2 \%$ of their net profits to the CSR, and there are many amendments made in this Act afterward (Khandelwal \& Swarna, 2014). Due to COVID-19, regulators have announced that companies can deposit an equal amount of CSR in the Prime Minister's Relief Fund. It is considered to fulfill its obligations for CSR (Business Today, 2020). Since 2014, when the CSR Act came into existence, the total amount of CSR spent by companies stood at 10066 crores which increased up to 13,624 crores until the end of the financial year 2017-2018, covering 28 different development areas and all the 36 states and UTs of India (refer to Table 1). It is observed that the contribution of government companies had declined gradually over the last 4 years, from 2816 crore to 2553 crore, while non-government companies have contributed 7249 crores in 2014 , which increased up to 11,070 crores in 2018 . The amount spent on CSR activities by the listed companies was around 1832 crores in 2014 and 2102 crores in 2018. But the unlisted companies spent around 14,716 crores in 2014, increasing to 19,295 in 2018.

Companies that have contributed above 50 lakhs to 1 crore for CSR were 662 in 2014, increasing to 1072 in 2018 . The deep insights into these numbers have made the researcher rethink and motivated to research whether it is valid in all sense. The financial institution's reputation entirely relies on its socially responsible programs and related investments (Poolthong \& Mandhachitara, 2009), so that only banking institutions tend to have a high ranking on the international CSR investment ranking index, which will impact the national level indexes (Perez et al., 2013). The banking sector has made significant transformations in the last few years. It has become one of the main proactive CSR activities worldwide (Marin et al., 2009; Truscott et al., 2009) because these investments are highly correlated to the national level indexes. The economic index for evaluating CSR investments is a widely used literature (McGuire et al., 1988; Spencer \& Taylor, 1987; Waddock \& Graves, 1997).

In the past, selling stake by HDFC bank to a Chinese bank, continuously increasing NPAs of the banks due to significant loan defaulters, and RBI's efforts to make the Indian banking sector achieve the minimum efficiency level at least. This scenario started with the failure of YES Bank. 


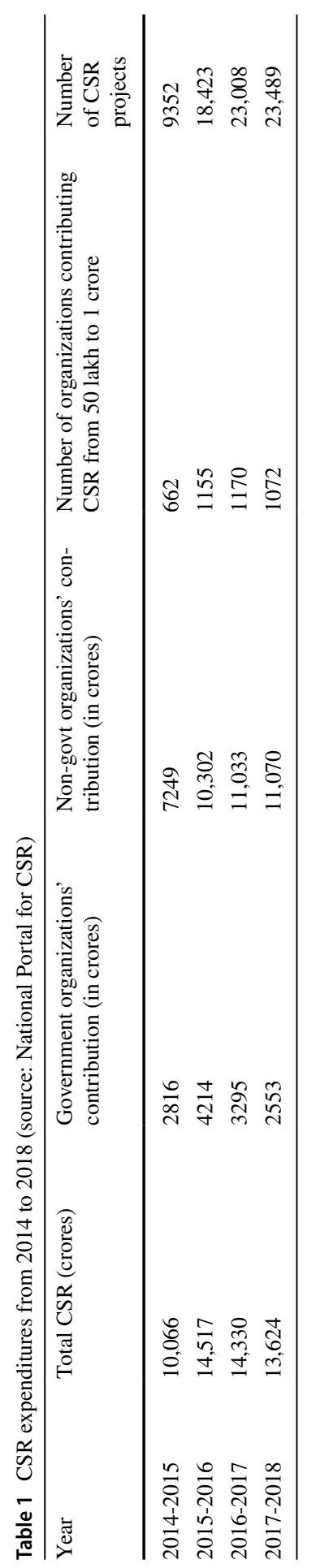


The Indian banking sector has reached the current phase of struggling from a glorious degree due to a lack of transparency and several loopholes in the system. Besides, Indian banking sector had intense competition and started taking CSR activities very seriously (Fatma \& Rahman, 2014). Some banks have mentioned the amount in the annual report is not used for CSR activities. In this decade, even though regulatory bodies made CSR spending mandatory, banks are willing to spend the real money because it helps establish brand identity and brand positioning among the consumers (Georgiadou \& Nickerson, 2021). Indian banks are using this as one of the marketing strategies to improve their ranking and rating voluntary because consumer recalling power and brand loyalty is very high (Fatma \& Rahman, 2014). During COVID, RBI insisted the banks transfer the unspent amount of CSR converted into CSR corpus to the PM relief fund for national causes, so banks were highly tuned towards spending these investments voluntarily for their brand-building exercises.

The misrepresentation of facts or authenticity of the disclosures by the banking sector got highlighted and raised numerous questions on the considerable amount of CSR to spend by the banks while facing a massive amount of NPA and other losses. But the economic development index is telling a different story. Bank's investments in the last 3-5 years should reflect in the indexes which are directly connected to the country's economic development. But the index results depict that the economic growth is not that proportionate to the investment done by the bank. But many companies are contributing a massive amount to CSR, so why is the country's economic growth still too low? Are the banks using these CSR activities as only brand-building exercises and marketing tools for their better brand visibility?

The Indian banking sector is a highly contributing sector towards economic growth. It tends to be responsible towards society, as it involves a direct interest of the general public. This is one of the fundamental reasons why banking institutions focus more on CSR activities (Perez et al., 2013). Despite the increasing interest in CSR in this industry, no studies have measured the impact of CSR activities in the banking industry on the country's economic growth, especially in developing economies like India, so the present study focuses on the Indian banking sector, and the main objective is to identify the association between CSR and economic growth.

This dilemma leads to another aspect: Is there any transparent approach that helps the banks invest in suitable projects that support the country's economic growth? The following research questions are framed based on this argument.

RQ1: Whether CSR activities of the bank contribute to Indian economic growth or not?

RQ2: Are CSR activities used only as a marketing tool by the banks?

RQ3: Is there any approach for banks to make practical CSR activities that leads to better economic development?

In the present study, the researcher has tried to link the economic growth with the CSR spending of the banks. Later on, the discussion has been made related to the CSR Act, contradictory disclosure of the unspent amount of CSR with the companies, and no perceptible change in the Indian economy despite an enormous CSR 
spending by banks. This paper focuses on whether CSR is a myth or fact and how banks use CSR activities as a marketing tool. Finally, this paper will suggest practical approaches for government and policymakers to make CSR activities more impactful and long-lasting, which will impact economic growth. Researchers have first focused on finding out the relation between CSR activities and economic development. Once it proved there is no significant relationship between CSR activities and economic growth, researchers have further explained the reason using the "YES Bank" case. YES Bank is failed in the market, being part of index ranking for CSR activities and sustainability, whereas in non-of the bankers cannot be part of the list even though they are substantial in terms of customer base and total assets. Hence, the study will prove both the parts of the statement "CSR as a "myth" or a "fact.",

\section{Review of literature}

The literature review is divided into two parts: the first part focused on studies that established the link between CSR and economic growth. The second part of the paper is how banks use CSR as a marketing tool and proposal on the better approach of CSR activity investment which has a direct impact on economic development.

\section{CSR activities contribute to economic growth}

As per Table 2, various CSR activities practiced by the banks have a positive and significant contribution to the economic development of any nation. CSR activities include rural development projects, protection of the environment by effective utilization of resources (Mahapatra \& Mohanty, 2013) and carbon footprints (Tilton, 2003; Castro, 2004), and development of infrastructural facilities for providing provision of healthcare facilities to the individuals (Howell et al., 2003; Vastradmath, 2015; Verma \& Chauhan, 2007). The institutions establish multiple business ventures across the rural and remote areas to enable the residents to become self-reliant (Mishra \& Modi, 2012; Netar, 2017). In contrast, some are making their efforts towards providing life-supporting healthcare services to improve the living standards of the underprivileged sector of society (Wong et al., 2011). Sen (2017) documented that the organizations involved in diverse spheres to pursue their CSR activities view the social and environmental dimensions (Verma \& Chauhan, 2007). Numerous researchers also support it (Dobers \& Halme, 2009; Lee-Davis, 2017; Navarro Espigares \& Lopez, 2006; Valor, 2005) that these activities like education and skill development are linked to increasing income and reducing unemployment and growth rate of the economy. Various indexes like income index, education index, gender development index, human development index, inequality index, unemployment rate, life expectancy rate, and natural depletion rate are the various indexes that measure the economic growth of the country (Tang et al., 2012).

Unlike the banking industry, every industry contributes to the national economy by investing its money in CSR activities. Still, the banking industry's contribution is higher than any other industry, leading to a better national economy (Tang et al., 


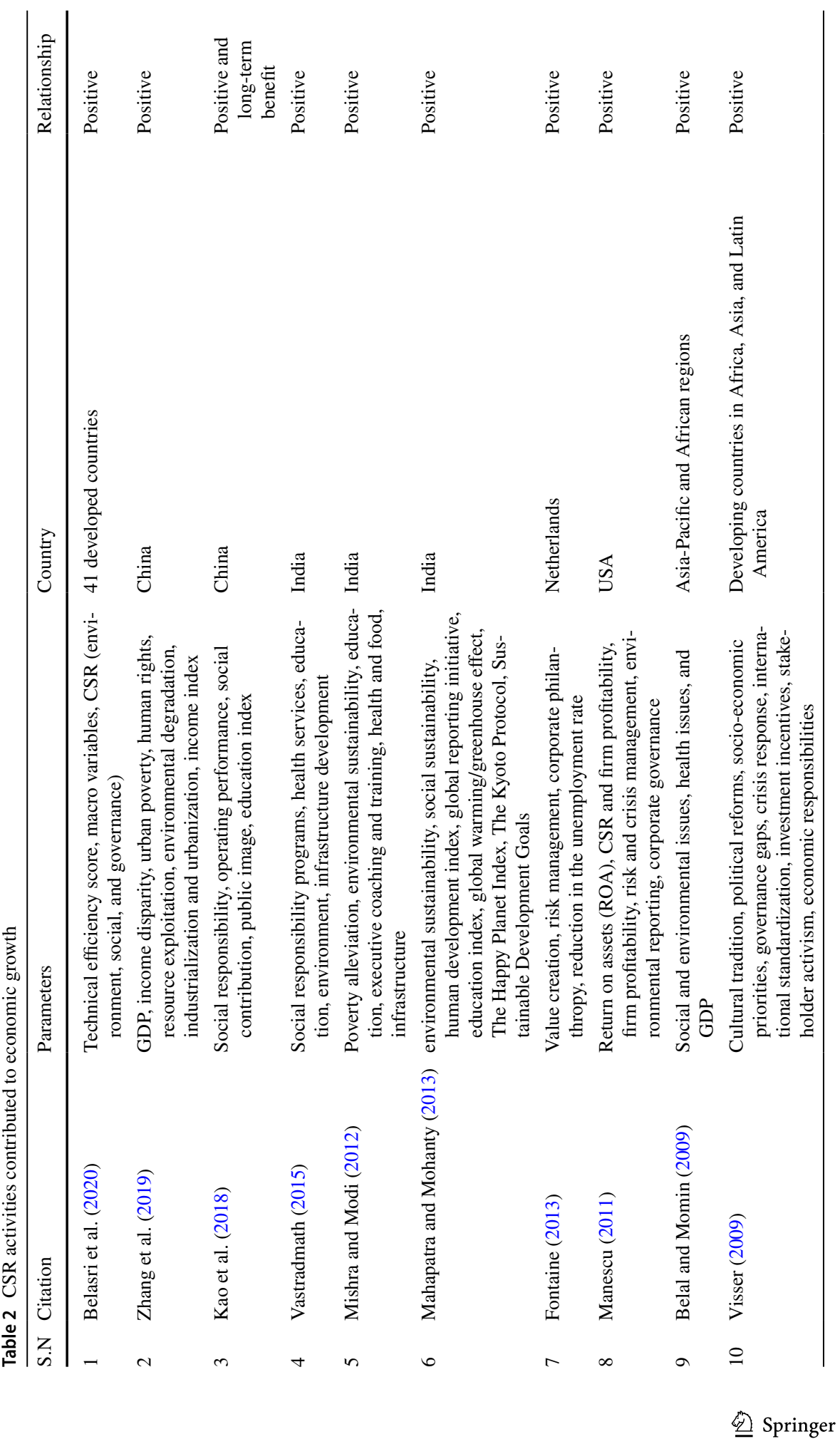




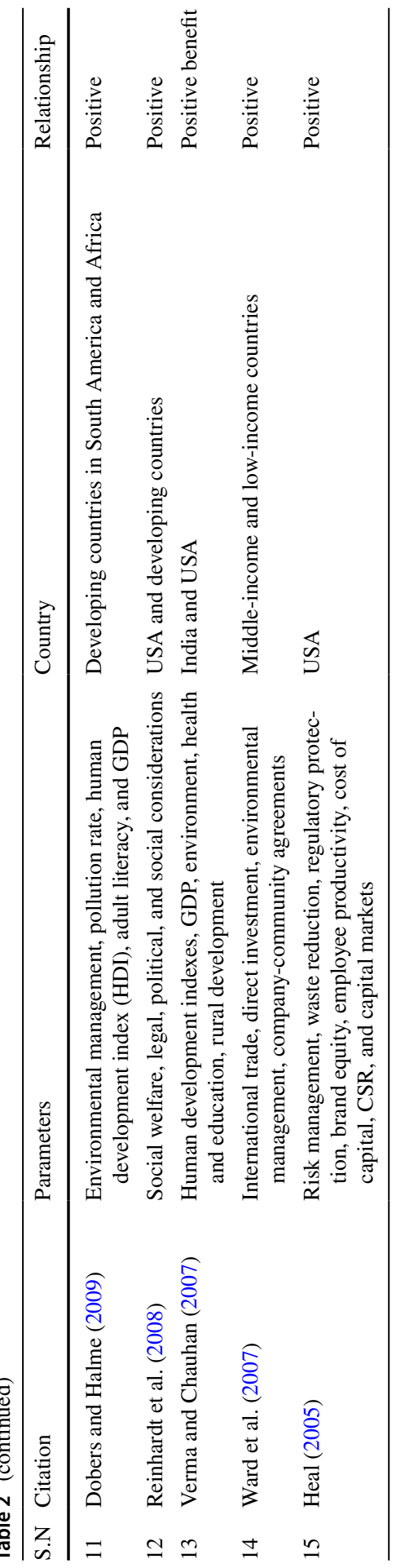


2012). The interesting observation is banking industries invest in CSR activities as a proactive engagement, but other sectors invest in CSR due to external stakeholder pressure (Decker, 2004), so the banking sector majorly contributes to economic growth among financial institutions.

\section{CSR activities are considered a tool for marketing by the banks}

As per the holistic insights of the studies undertaken by the eminent scholars discussed in Table 3, it is evident that the decision-makers in the various institutions in the emerging economies underpin the actual CSR practices. They are engrossed in namesake CSR practices to comply with forcefully imposed conditions. The above factors undertaken to satisfy the expectations and mitigate the pressure are assessed by international buyers, political leaders, and regulators. Many eminent scholars (Balmer \& Greyser, 2006; Delmas \& Burbano, 2011; Lyon \& Montgomery, 2015; Ting, 2020) in their studies have reflected the use of CSR by many big firms as a means to earn global fame, to gain the attention of customers and investors, and to retain long-term sustainability in the market. The organizations often talk of their CSR activities as the actual actions, structural transformations, and changes in business processes, which becomes a costly affair (Wickert et al., 2016).

In their study, Lyon and Montgomery (2015) have admitted a significant impact on their brand image. They listed CSR activities like women empowerment and environmental sustainability, besides engaging the external stakeholders to perform in their names which increases the brand's visibility (Campbell, 2007; Khan, 2016).

Many studies found that CSR reporting is just like a window dressing act, which they use to promote their image by publicizing their commitments and faux performances to meet the regulatory compliances, but without being involved in the actual implementation of their so-called commitments (Behnam \& MacLean, 2011; Cho et al., 2010). Jo and Harjoto (2012) and Khan et al. (2013) revealed that large firms use CSR reporting as a way to communicate their pre-decided commitment to CSR activities to gain legitimacy from the government authorities (Uddin et al., 2016).

But still, the firms hardly pay any heed to implementing them precisely and state that the firms use CSR reporting to publicize the excellent reputation, esteem, and goodwill, and build a brand name (Moravcikova et al., 2015). Besides, CSR reporting demonstrates self-appreciation (Shapiro \& Matson, 2008), efficiency, and awareness among the management regarding their responsibilities towards its stakeholders, economy, and environment (Wensen et al., 2011).

The awareness about the economic benefits of CSR for the company can help plan and implement CSR activities, so it can be used as a tool for sustaining in the market during the recession period. This concept was well-practiced by the aviation industry of Turkey, which uses its CSR activities for coming out from the global recession of 2008 (Durmaza et al., 2011). The literature review portrays that the CSR activities performed by various organizations in emerging nations like India, either philanthropic or about the preservation of biodiversity, are carried out to restore the organizations' immunity to sustain in the long run. Firms also try to align their corporate objectives with the interest of the stakeholders to magnify the outcomes of 


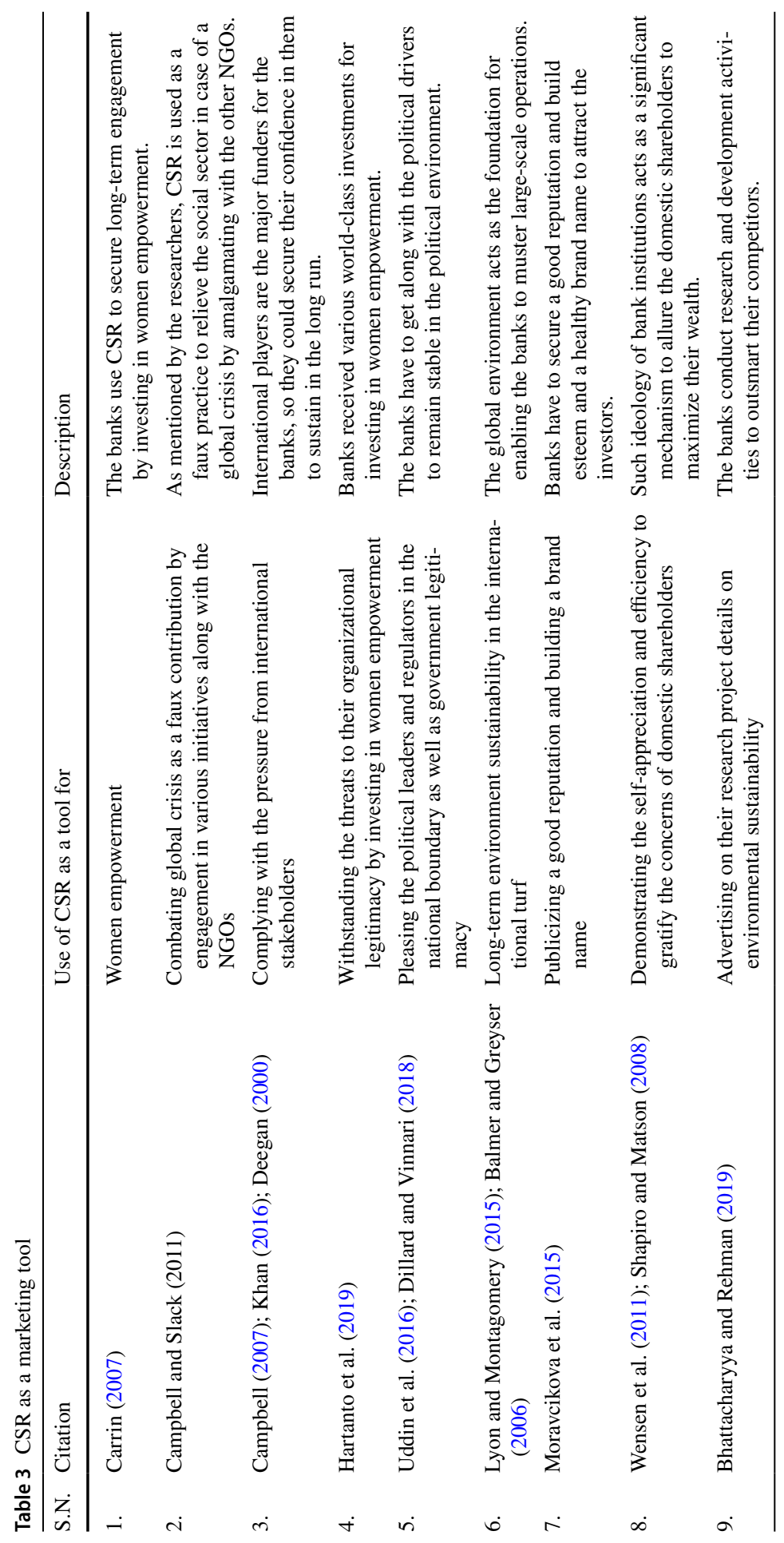


their CSR activities, especially on women empowerment and environmental sustainability, because this factor impacts so many indexes (Khojastehpour \& Riad, 2019). Engaging the stakeholders in the CSR activities proved to be the best tool for the company's self-promotion (Lim \& Greenwood, 2017). Fatma and Rahman (2014) stated that any communication about the company's CSR activities cannot be trusted as companies mainly disclose the CSR activities they are not doing or have not done. Hence, media cannot be trusted as credible CSR communication sources.

Building a corporate image needs something beyond the product and services, especially in the banking industry (Perez et al., 2013). CSR activities are considered one of the powerful strategic tools in marketing because it increases the brand image and brand perception (Hartanto et al., 2019; Arendt \& Brettel, 2010; Chong, 2009; Du et al., 2010). Various tools are used as a part of CSR activities in that women empowerment is the pivotal activity operated by the banks (Maignan \& Ferrell, 2000; Turker, 2009). Some researchers have revealed the firms make constant efforts for the development and well-being of women (Carrin, 2007), as well as girl child development by providing adequate employment opportunities (Kashyap \& Choudhury, 2014).

Various efforts like providing education facilities and introducing the skill development projects and environment sustainability (McGrath, 2011) contributing towards lowering the gender disparities and reduction in the unemployment rate (Acharya, 2006) are factors contributing towards the empowerment of women (Hartanto et al., 2019). These are the most commonly used projects as part of CSR activities by the bank.

The development of the economy is measured by the gender development index (Carrin, 2007). The impact of CSR activities like education, health, community development, and infrastructure development are reflected in the human development index (Hartanto et al., 2019; Pieter, 2010). Increasing the soft skills of women leads to self-employment, self-empowerment, and creating more job opportunities for women which are reflected in the gender inequality index (Hartanto et al., 2019). Factors like green environment, carbon emission rate, and natural resources savings are measured and reflected in the environmental sustainability index (Mittal \& Gupta, 2015; Verma \& Chauhan, 2007 and Whitehouse, 2006). Based on the argument's hypothesis (6 to 11) is formulated to test whether CSR activities are used as a tool for marketing.

So if the banks invest considerable investments in CSR projects, that should reflect the country's economic development. But various indexes are not reflecting the same. For the past 3-5 years, the investments have not made any profound impact on the index that measured the country's economic development. So, considering women empowerment as a significant CSR activity that developed as a powerful marketing tool, the banks are using this serious marketing tool to enhance their brand visibility and image. 


\section{Research gaps}

Several research studies examined the link between CSR investments of the corporates and their financial performance (Margolis \& Walsch, 2003; Skare \& Golja, 2014). Many studies have also linked the various determinants like per capita income and degree of capitalism, with economic growth (Acemoglu, 2009; Aghion \& Howitt, 2009; Barro \& Sala-I-Martin, 2004; De La Croix \& Michel, 2008). As per the CSR literature, recurring distractions between the global expectations and local opportunities or challenges in developing the CSR practices across the emerging economies are evident (Newell, 2005). Moreover, the critics have argued that the drivers of CSR practices, which are relevant in the Western nations, are not supportive and appropriate in the emerging countries (Jamali \& Mirshak, 2007; Nielsen, 2005). Many types of research regarding the CSR activities of different institutions in the developed nations have been taken out (Fontaine, 2013; Heal, 2005). The last few years have witnessed substantial growth and development, which have taken place in several emerging nations like Bangladesh, China, Indonesia, and Brazil, with the introduction of CSR practices being initiated and promoted by the banking sector by complying with the CSR regulations and norms (Khan, 2016; Khan et al., 2011; Khan et al., 2014).

As far as India is concerned, the nation has been influenced by the pressures from the international players' actions of various stakeholders like regulators and political leaders. The banking sector plays an essential role in the economy, growing steadily by leaps and bounds. The banks have also engrossed CSR practices to keep up with the pace of guidelines provided by the government for their smooth persistence in the dynamic and demanding scenario in India. Many qualitative studies depict the CSR performances of the different banks based on multiple global CSR indexes that were considered in the past. Still, limited quantitative research is conducted on CSR practices within the banking industry in India (Khan, 2016). Some research works have provided generic discussions and references to distinctive performance tactics without exploring the phenomenon discussed in that framework. Moreover, the previous studies have neglected the link between the banks' actual amount spent on CSR activities across different spheres and their actual impact on the economy's growth.

Various literature proved that various industries contribute towards CSR activities in that banking sectors invest in CSR projects like education, skill development, rural development, activities related to reducing unemployment, and healthcare activities. But the interesting observation is that the various indexes that is treated as economic growth measure are not indicated the same. There is scope to prove that CSR investments done by the banks are seriously impacting the country's economic growth, or these activities are used as a marketing tool for the banks, which enhances their brand visibility and image among the stakeholders and customers.

\section{Research methodology}

CSR Act, 2014 made it compulsory for all the banks and non-banking institutions operating in India to invest $2 \%$ of their net profit for development and social activities. In recent times, all the Indian organizations started disclosing the total amount 
of CSR in their annual reports. But still, some of the banks in India admit only the total amount spent on CSR in their annual reports and have disclosed nothing about the development area-wise or activity-wise spending. Due to this limitation, the researcher has taken only those banks in the sample which have shown clear area-wise or activity-wise expenditures in CSR by the banks in their annual reports (list of banks is given in the Appendix). A sample of 21 commercial banks is considered for the study (list of sample banks is annexed as Appendix). The period of the data was 2014-2015 to 2017-2018, and both state-wise and pan-India wise CSR spending have been considered for analysis purposes. Even though all the banks are spending money on CSR activities, only these 21 banks have disclosed the amount spent on CSR activities like women empowerment, self-employment, and improving soft skills. Two significant variables have been used in the study: one is related to banks' CSR, including the development area-wise spending and total CSR spending; another major category of variables was taken as a proxy for economic growth. Here, indicators used by the United Nations for measuring the human development index of a country have been taken as proxy variables to reflect India's economic growth, along with a change in gross domestic product (GDP) rate and gross state domestic product (GSDP). Sources of the secondary data related to CSR spending were annual reports of the banks, the Indian National Portal for CSR, the United Nations data sources for the human development index of India, and its significant indicators.

\section{Hypothesis development}

The following section deals with the formation of hypotheses for the research work. The research hypothesis has been framed based on the findings of the studies conducted by eminent scholars and through literature.

RQ: 1 Whether CSR activities of the bank contribute to Indian economic growth or not?

\section{H1: CSR activities of the banks positively impact the economic growth rate of states and the economy as a whole.}

The institutional practices that imbibe the interests of all stakeholders and reflect the actual work done portray the aspect of corporate social responsibility among the various agencies and undertakings. When the institutions work as per the norms and regulations set by the government, their actions increase the possibility of positive transformations in the economy's gross domestic product. All the CSR practices in precisely recognized domains mainstreaming the underprivileged people of the economy result in the growth of the social sector. The studies conducted by Navarro Espigares and Lopez (2006), Dobers and Halme (2009), Mittal and Gupta (2015), and Lee-Davis (2017) have propagated that CSR activities of the organizations have a positive impact on increasing the nation's growth rate. Therefore, the study will 
aim to ascertain whether the outcomes of realistic CSR practices of the banking institutions have been reflected in the nation's economic growth.

CSR activities like rural development projects, education and skill development, livelihood enhancement projects, and healthcare are contributing to the index, which are the measures of economic growth.

\section{H2: CSR spending on rural development projects by banks leads to an increase in the income index of a nation.}

The investment programs were undertaken to create the institutional platform for socially and economically mobilized individuals in rural areas, which leads to a reduction in poverty and improvement in the living standard of the individuals. These programs act as a source of livelihood to the people and a bridge to reduce the regional disparities and stimulate several macro-level indicators like income and expenditure. The increase in self-employment opportunities also enhances individuals' purchasing power, resulting in the development of the economy. Some scholars like Hancock and Bauman (2012) and Netar (2017), in their research works, have illuminated the positive relationship between rural development and the income of the economy. The present study tries to reflect the impact of CSR activities conducted by the banking institutions related to rural development projects on the income index of India.

\section{H3: CSR spending on education and skill development by banks lead to an increase in the education index of a nation.}

The government and private institutions' introduction of literacy enhancement programs enables individuals to develop their autonomous mechanisms and play an essential role in developing the economy. The implementation of skill development programs requires the active involvement of individuals. The literacy rate reflects the level of education among both genders. But in the discriminatory environment, the individuals must take the initiative to send their girl child to the schools. It can enable the girl children to teach the required proficiency to excel in their lives. A nation can only step forward on the progressive ladder with educated and aware individuals. In his studies, McGrath (2011) has depicted the positive relationship between education and skill development among the different strata of society and their literacy. The present study focuses on examining that the CSR expenses in the field to disseminate education, knowledge, and develop skills of the individuals result in a rise in the education index of the economy.

\section{H4: CSR spending on livelihood enhancement projects by banks reduced the nation's unemployment rate.}

Some inclusive projects provide financial and technical assistance to individuals to make their living, and thus help the nation reduce poverty in less developed areas. The facilitation of the self-help group-based approach converges the gains in developing productive assets and mainstreaming the disadvantaged section of 
society. Such attempts with public-private partnership leverage the transparency accountability and strengthen the local governance resulting in more bottom-up project reforms. On the other hand, such constant inputs keep persuading individuals to avail themselves of employment opportunities leading to better living. In their research works, Acharya (2006) and Netar (2017) have propelled the tremendous impact of livelihood enhancement projects in reducing the unemployment rates across the under-exploited or rural areas. The research aims at finding whether the CSR practices executed by the banks to generate livelihood result in a reduction in the unemployment rate in the economy.

\section{H5: CSR spending on healthcare by banks lead to a rise in the life expec- tancy rate of a nation.}

Health is one of the essential parameters to reflect the human development index in the economy's growth rate. Healthy individuals have the creativity and ability to devise their ideology and energy into productive outcomes. The development of proper healthcare infrastructural facilities is necessary, keeping in view the disposable income of the individuals. The adequate income would enable the individuals to access healthcare facilities leading to a higher life expectancy rate. Howell et al. (2003) and Wong et al. (2011) revealed in their studies that exposure to healthy living and healthcare facilities is positively correlated with the life expectancy rate. The present study would attempt to analyze whether the CSR expenditure of banks in healthcare has led to a higher life expectancy rate later on.

\section{RQ2: Are CSR activities used only as a marketing tool by the banks?}

\section{H6: CSR spending on women empowerment by banks leads to a rise in the gender development index of a nation.}

Active engagement of women in decision-making plays a significant role in empowering women. The large-scale opportunities across social, political, and economic domains have enabled the women to acknowledge and propel their roles as active agents in nation-building. When women are exposed to wider opportunities, they become self-reliant and capable of outshining the prejudices against them in a male-dominated society. In their results, Carrin (2007) and PNDA Guidelines (2015) portrayed that exposure of women to more inclusive opportunities has a positive correlation with gender development in the economy. The present research attempts to explore whether the CSR expenses made by the banks in the domain of women empowerment would lead to an improvement in the gender development index of the nation.

H7: CSR spending on women empowerment by banks leads to a rise in a nation's human development index (females). 
Women play an essential role in the development of the economy. Women's contribution and active engagement laid the foundation for an inclusive society. The investment in several domains like health, education, income, community development, and infrastructural development, keeping in view the upliftment of women, brings positive changes at the domestic and global levels. Hartanto et al. (2019) and Pieter (2010), in their studies, have mentioned the positive outcome of women's empowerment in terms of their overall development and improvement in their standard of living. The present study endeavors to analyze whether the bank's CSR expenses were made to empower the women to enhance the human development index of females or not.

H8: CSR spending on women empowerment by banks leads to a reduction in the gender inequality index of a nation.

The modernization process has made the women more focused on marking their presence against the victimization of biases and inequality either at the workplace or in domestic lives. The government and corporate sector have acknowledged the contribution of women in nation-building. Women have recognized their potential in bringing pride to the nation. There should be equal opportunities in self-employment activities and professional engagements. Kashyap and Choudhury (2014), in their studies, have reflected that the introduction of opportunities to empower women reduces gender inequality in the nation. The current research aims at enquiring if the banks take up the CSR initiatives to enable women would result in the gender inequality index later on.

\section{H9: CSR spending on community development by banks leads to a rise in the human development index of a nation.}

The accommodation and execution of plans at the grass-root level lead to the development of the economy. A holistic and inclusive approach focuses on investment in prominent sectors like education, health, generation of employment opportunities, and infrastructure, which results in the overall improvement in the social sector. Mainstreaming the underprivileged into the immediate investment plans also boosts the possibility of a rise in the human development index and contributes towards strengthening the economy. The studies conducted by eminent scholars like Tai-Kei and Coates (2002), Valor (2005), Gallardo (2009), and Hartanto et al. (2019) have depicted that investment in community development projects results in human development. The current research endeavors to analyze if the CSR practices of banks for community development positively result in improvement in the human development index in the economy.

H10: CSR spending on environment sustainability by banks lead to a reduction in carbon dioxide emission rate.

Environmental sustainability focuses on conducting the activities by concentrating on economic growth, equity, and environmental quality. The excessive 
utilization of natural resources leads to an increase in the emission of carbon footprints, which also harms biodiversity. Isonel et al. (2009) disclosed in their studies that the activities conducted by various organizations on the grounds of sustainability result in a reduction in the emission of carbon dioxide. The study examines if CSR activities performed by the banks would reduce the emission of carbon dioxide.

\section{H11: CSR spending on environment sustainability by banks leads to a reduc- tion in natural resources depletion rate.}

Environmental sustainability relies on the democratization of control over natural resources and their consumption rationally. The natural resources are found in abundance but often polluted and depleted due to human activities. It is done with the production and consumption of commodities at a large scale by leveraging technology and implementing several development strategies. The studies conducted by Tilton (2003), Mittal and Gupta (2015), and Verma and Chauhan (2007) revealed that the environmental sustainability practices significantly lead to a reduction in the depletion of natural resources. The present study elucidates that CSR expenses made by the banking institutions using a sustainable approach should reflect a reduction in the lack of natural resources.

RQ3: Is there any approach for banks to make effective CSR activities that leads to better economic development?

The practical approach named "SPCLF," which banks can practice for making CSR long-lasting and impactful activities that can help the nation in growing at a rapid rate, is given below:

(S) Strategic CSR The inclusion of CSR acts as the imperative component in the organizational strategies as a perfect combination of organized philanthropy and the economic pursuits as well, at the local, national, and global turf depending upon the scale of their operations (Porter \& Kramer, 2006). The banks are supposed to utilize their corporate social responsibility resources precisely to have a long-lasting and sustainable impression on the society and environment (Afrin, 2013). There is a need to replace the antiquated CSR ideology with a strategic CSR approach, which enables the banking institutions to proceed with genuine CSR activities that are fruitful and sustainable to the institutions in terms of financial and human resources (Lee-Davis, 2017). It is sometimes observed that the institutions carry out several CSR activities to fulfill the terms of the Memorandum of Understanding only. The strategic CSR depicts the linkage between the CSR operations and banks' business processes and initiatives such that they may have an exponential and visible impression on the concerned stakeholders (Werner, 2009). Strategic CSR is the need of the hour to enhance the institutions' value-creating practices and indulge in the institutions' day-to-day functions (Gill, 2007). Strategic CSR imbibes the inclusiveness approach, i.e., carrying along with the interests of external and internal stakeholders to channel the productive outcomes in the present and future. 
(P) Passionate leadership The management of the banks is required to perform being true leaders of the institutions depicting certain significant traits like effervescence towards their work, commitment for the projects undertaken, optimistic ideology, and inspirational leadership to steer the values and projects into reality (Davies \& Brighouse, 2010). In the present scenario, all the banks are involved in CSR activities; in turn, every institution is required to perform at an astounding rate for its survival in the highly dynamic arena (Lee-Davis, 2017). The work "leadership" is incomplete without "passion" and "ethics" as it acts as a push factor to make the institutional authorities take up the challenges, have the adaptability towards the transformational circumstances, and depict the constant improvements in terms of confronting the unacceptable initiatives with the values and emotions possessed by them (Angus-Leppan et al., 2010). Being passionate leaders of banks, they have to stick towards the ideology of togetherness and diversity on the foundation of harmonizing the potentials and channelizing the interests of their employees, looking into their requisites, and putting strenuous efforts for their well-being well. The banks have to take the initiative to prepare their associates in the ventures to be very well aware of their expectations and their performance towards their well-being as per the actual values, norms, and ethics.

(C) Concentration instead of diversification The banks have to engross in some confined activities instead of a plethora of activities, making it daunting for the institutions to ascertain the right partners and locale. Most of the time, it results in the misappropriation of the CSR funds (Afrin, 2013). The confined domains chosen wisely by the institutions on the foundation of their access to the periphery and interests of the stakeholders have visible impacts on the respective habitats contributing towards the nations' growth (Anderson et al., 2003). There is a direct link between the concentration of activities up to certain well-acknowledged and well-acquainted domains rather than focusing on diversifying across numerous broader disciplines to prove to the mark as per the competitive environment (Aguilera et al., 2007). It reduces the complexities and unproductive experimentation having negative impacts on the social and environmental spheres in which these institutions exist (Baron, 2007). The concentration of CSR practices also enables the institutions to carry out more research and development practices to enhance their specialization and good image among the community and other stakeholders (Brammer \& Millington, 2005). The banks must continue their CSR activities in one specific and its allied activities instead of following a long-listed approach of actions. Diversification in terms of health, education, housing, transportation facilities, women empowerment, child development, support to physically challenged, and promotion of art and culture make the activities more entangled and purposeless. In contrast, the concentration in terms of holding on to a specific segment of the society, such as women, and making all the best possible efforts to uplift them seems sound and productive.

(D) Linking CSR programs with the business processes The institutions carry the CSR initiatives based on the foundation of philanthropic practices. They must link up with the adoption of activities defining the sustainability of the local community 
and environment around them (Hohnen \& Potts, 2007). The banks have to perform their CSR activities by keeping into account the interests of all the concerned stakeholders, including suppliers, employees, environment, and community (Vilanova et al., 2009). The CSR programs carried out by the banking institutions must be in close consortium with the financial performance leading to their progression, corporate image, competitiveness, and enhancing the level of satisfaction among the stakeholders as well (Pedrero et al., 2019). Instead of ad hoc charity of activities, the banks should focus on strengthening the business projects and stabilizing the processes like accepting the green supply chain of operations to have positive outcomes for general and particular stakeholders of the institutions, environment, and economy. The activities are supposed to be planned to keep in view the institutions' actual essence, and all the projects carried out have to be in line with the primary functions. It is complicated to perform CSR activities being stuck across several specific domains, such as education, promotion of artisans, and sports activities. Instead, the banks must be engrossed in enabling the individuals to be independent and earn their livelihood. Activities include upliftment of education, promotion of vocational training, initiating several seminars, skill development programs, and providing infrastructural facilities to promote their functioning either in the city's outskirts or in the rural areas to make the people self-employed.

(E) Feedback mechanism The banks are involved in the CSR practices in multiple ways, such as direct involvement in the philanthropic initiatives, functioning through the trusts, and working in close association with the other implementing agencies (Pedrero et al., 2019). Most of the institutions work in partnerships with the NGOs, and the entire onus to be in touch with the people is borne by these organizations. The institutions do not pay heed to take feedback from the beneficiaries to ascertain the utilization of their CSR funds and their impact on them (Glavas, 2016). Banks must be actively involved in the entire phases of investment in the adequate domains, which is to be chosen wisely as per the pre-requisites and the fair set of parameters to enhance their whole selves with the banking institutions (Gallup, 2013). The banking institutions have to involve themselves in constant monitoring of all the actions and initiatives taken in the periphery areas using the proper selection of domains and agencies to support them in turning their plans into realistic projects (Hulin, 2014).

Hence, banking institutions are supposed to indulge in such practices to provide long-lasting benefits to the different strata of the stakeholders in the nation by introducing such reformative and innovative techniques at constant intervals of time. They must redefine their primary focuses and keep in proximity with the ongoing trends in emerging economies like India, where more emphasis is to be laid on the growth and development of the social sector. The inclusion of these aspects in the day-to-day operational strategies of the banking institutions would enable them to maximize the potential output by eliminating all the evils existing in the society like poverty, pollution, instability, and illiteracy (Verma \& Chauhan, 2007).

The executions of the approach proposed in the research would certainly bring positive outcomes on the stakeholders, economy, and environment in the highly complex environment. The study would also expand the prospects for the 
government and non-government institutions to volunteer into CSR practices to reach the actual gains positively.

\section{Results of analysis}

A gross amount of 2888.15 crores INR has been spent by 21 banks, including private and public sector banks of India, during the year 2014-2015 to 2017-2018, on eight major development areas, namely art and culture, community development, education and skill development, healthcare and sanitation, environmental sustainability, livelihood enhancement projects, rural development projects, sports welfare, and women empowerment. Out of which, 546.45 crore INR were spent on CSR in 2014-2015; 620.01 crores in 2015-2016, 820 crores in 2016-2017, and 870.62 crores in the year 2017-2018 respectively. CSR activity-wise link with the economic development of India has been discussed in the subsequent sections.

\section{CSR_development sector-wise analysis}

All the 21 selected banks have invested highly in the rural development projects, which amount to $122,104.4$ lakh rupees from 2014-2015 to 2017-2018, while the second development area where the banks have invested highly for the same period was education and skill development (Tables 4 and 5). Banks' least focused area for CSR was women empowerment and art and culture, with a total investment of 746.61 and 990.65 lakh rupees, respectively. Hence, the development sector, rural development, and education were two significant areas where banks made CSR spending. CSR activities related to rural development include the expenses on farmer welfare, rural education, rural financial literacy rate, and providing resources for livelihood. Banks' education and skill development expenses include the CSR activities for the development of educational institutions, scholarships, donations to

Table 4 CSR expenses (amount in lakh rupees)

\begin{tabular}{llllll}
\hline Development sector & $2014-2015$ & $2015-2016$ & $2016-2017$ & $2017-2018$ & Total \\
\hline Art and culture & 255 & 281 & 222 & 232.65 & 990.65 \\
Community development & 2650.84 & $17,689.21$ & $12,585.1$ & 3556.83 & $36,481.98$ \\
Education and skill development & $21,758.7$ & $11,630.1$ & $10,438.74$ & $13,664.74$ & $57,492.28$ \\
Environmental sustainability & 3234.1 & 4820.11 & 4415.96 & 4336.88 & $16,807.05$ \\
Healthcare & 3196.71 & 1996.92 & 3900.39 & 3398.99 & $12,493.01$ \\
Livelihood enhancement projects & 2625 & 4644 & 12,924 & 19,866 & 40,059 \\
Rural development projects & $20,785.94$ & $23,553.85$ & $36,445.81$ & $41,318.8$ & $122,104.4$ \\
Sport welfare & 21 & 230 & 848 & 541.07 & 1640.07 \\
Women empowerment & 117.83 & 258 & 224 & 146.78 & 746.61 \\
Grand total & $54,645.12$ & $65,103.19$ & 82,004 & $87,062.74$ & $288,815.05$ \\
\hline
\end{tabular}


Table 5 Economic growth parameters from 2014 to 2018

\begin{tabular}{lllllll}
\hline Variables & 2015 & 2016 & 2017 & 2018 & Correlation value & Hypothesis \\
\hline GDP growth rate (\%) & 7.4 & 8 & 8.3 & 7 & -0.053 & H1: reject \\
Income index & 0.61 & 0.62 & 0.63 & 0.64 & 0.965 & H2: accept \\
Education index & 0.54 & 0.56 & 0.56 & 0.56 & -0.946 & H3: reject \\
Unemployment rate & 2.8 & 2.7 & 2.6 & 2.6 & -0.884 & H4: reject \\
Life expectancy & 0.75 & 0.75 & 0.76 & 0.76 & 0.402 & H5: reject \\
Gender development index & 0.82 & 0.83 & 0.83 & 0.83 & 0.452 & H6: reject \\
HDI (female) & 0.55 & 0.57 & 0.57 & 0.57 & 0.366 & H7: reject \\
Gender inequality index & 0.55 & 0.54 & 0.52 & 0.5 & -0.004 & H8: reject \\
Human development index & 0.63 & 0.64 & 0.64 & 0.65 & 0.157 & H9: reject \\
Carbon dioxide emission & 1.4 & 1.6 & 1.5 & 1.6 & 0.883 & H10: reject \\
Natural resource depletion & 38.4 & 37.9 & 36.7 & 36 & -0.446 & H11: reject \\
\hline
\end{tabular}

schools, free books to schools, free development courses by banks, and other educational expenses. Now, these two areas will be analyzed more deeply.

Rural development-related CSR expenses of the banks increased from 20,785.94 to 41,318.80 lakh rupees from 2014-2015 to 2017-2018, and it has shown a continuous increase in the CSR spending of the banks in this development area. Comparing the CSR amount spent by banks on rural development and the income index of India for the same period, a positive and significant relationship came with a value of $r=$ 0.965 , at a $p$-value of 0.03 . Hence, the CSR spending by banks on rural development projects has contributed to the income generated in the economy, and the income index increased. CSR expenses by banks on the development of rural areas have significantly affected the growth rate of the income index of the nation. Banks have worked for the employment generation activities of rural people, improved their financial literacy, and made them self-sustaining, increasing the rural economy's income (Hancock \& Bauman, 2012; Netar, 2017).

Education and skill development expenses reduced from1758.7 to 13,664.74 from 2014 to 2018. Comparing these expenses to the education index of India, it found that there is a negative impact but significant relationship with the education index shown by $r=-0.946$, at $p$-value $=0.05$. CSR spending by banks on the educational and skill development sector has been reduced. In contrast, the education index of India, as per the UNDP report, has increased for the same duration i.e., 2014 to 2018. This shows that the CSR spending of banks on education and skill development have not contributed to the education index of the economy, which can be due to improper planning for these activities by banks or the lack of importance given to this area compared to other development areas (McGrath, 2011).

Banks in India have spent 2625 lakh rupees on CSR activities related to the livelihood enhancement projects, which has increased up to 19,866 lakh rupees during 2014-2018. Comparing the CSR spending of banks on livelihood enhancement projects and the unemployment rate, it was found to be a negative impact but insignificant relation shown with an $R$ value of -0.884 , at a $p$-value of 0.114 . Even though the banks have made considerable investments in livelihood 
enhancement projects, the nation could not significantly reduce the unemployment rate. It reflects either faulty planning for CSR activities in this area, not taking feedback after spending money on development activities, or banks' direct responsibility for conducting CSR activities (Acharya, 2006; Netar, 2017).

Total CSR spending for women empowerment by banks counts 117.83 lakh rupees in 2014-2015, which increased in the next year to 258 lakh rupees and then started reducing up to 146.78 lakh rupees in 2017-2018. CSR expenses on women empowerment compared with the gender development index found a positive but insignificant relationship with an $R$ value of 0.452 , at a $p$-value of 0.548. CSR expenses of banks on women empowerment compared with human development index for females found a positive impact but insignificant relation shown by $r=0.366(p=0.634)$. Comparing the gender inequality index with the CSR expenses of banks on women empowerment, negative and insignificant relation came out shown by $r$ value of $-0.004(p=0.996)$. CSR spending by banks on women empowerment has reduced, reflecting the banks' lack of importance towards development in this area. The increase in gender development index and HDI (females) results from government involvement in this area and policies framed by the government, not of the CSR activities of banks (Kashyap \& Choudhury, 2014; Pieter, 2010). Banks should realize that investing in the women empowerment area would lead to overall economic growth as women consist of almost half of the national population (Carrin, 2007; PNDA, 2015).

CSR expenses on healthcare were 3196.71 lakh rupees during 2014-2015, which increased to 12,493.01 lakh rupees in 2017-2018. CSR expenses on the healthcare sector compared with the life expectancy rate were positively but insignificantly related, as depicted by the $r$ value i.e., $0.402(p=0.598)$. CSR expenses by banks for community development increased from 2650.84 to $36,481.98$ lakh rupees during 4 years from 2014-2015 to 2017-2018. The human development index of India for the same period was compared with the CSR expenses of banks on community development, and results revealed that both are positively but insignificantly related as $r$ value came to be 0.157 , at a $p$-value of 0.843 . Banks have focused on healthcare and community development activities and have increased their spending on these areas year-wise. However, no significant impact can still be seen from these banks' efforts on the development of the nation in the parameter life expectancy rate or the HDI. It is clear that even if the banks are doing well in a particular development area, results are not as fruitful (Wong et al., 2011; Howell et al., 2003).

CSR expenses on environmental sustainability increased from 3234.1 to $16,807.05$ lakh rupees from 2014-2015 to 2017-2018. Compared to the carbon dioxide emission rate, CSR expenses on environmental sustainability were positively but insignificantly related $(r=0.883, p=0.117)$. The positive relation shows that even if the banks have made efforts to sustain the environment, there is still no reduction in carbon dioxide emission rate seen by the nation. The CSR expenses on environmental sustainability compared to the natural resources depletion rate were found to be negatively but insignificantly related $(r=-0.446, p=0.554)$. CSR expenses of banks increased for environmental sustainability, and the natural resources depletion rate has been reduced. Banks' effort towards environmental sustainability has not 
been reflected significantly in the nation's economic growth (Tilton, 2003; Almedia, 2002; Mensah and Castro, 2004).

CSR and GDP growth rate The correlation method has analyzed the relationship between the total CSR expenses of all selected banks during the 4 years from 20142015 to 2017-2018 and India's GDP growth rate for the same period. The value of $r$ was found to be -0.053 , which is insignificant too. Hence, CSR expenses by banks have no significant relationship with the economy's growth rate. To check this relationship more deeply, an attempt has been made to analyze the impact of the CSR activities of banks on the economic growth of state by using the CSR amount and the GSDP rate of states where banks have invested in CSR (Dobers \& Halme, 2009; Lee-Davis, 2017; Mittal \& Gupta, 2015; Navarro Espigares \& Lopez, 2006).

State-wise analysis of CSR activities of banks Banks have not shown a unique trend of investing in CSR for the same state every year. Rather, banks have shown a tendency to either invest in the state of where their headquarter is situated or have nuerous branches or on a pan-India basis (Graph 1).

Banks made the highest investment in CSR activities in Maharashtra, Madhya Pradesh, Jammu and Kashmir, and Rajasthan, while UTs (Delhi, Puducherry) and states, Mizoram, Tripura, Goa, and Telangana, have the lowest CSR investment by banks. Furthermore, the average GSDP growth rate of Goa, Mizoram, Karnataka, Sikkim, and Assam was found to be higher when compared to other states (refer to Graph 2). The relationship between the total CSR expenses of these states and their average GSDP growth rate was found to be negative and insignificant, with an $R$ value of $-0.214(p=0.293)$. If the banks are investing in a particular state in various development areas, it should reflect in the growth rate of that state, but in our

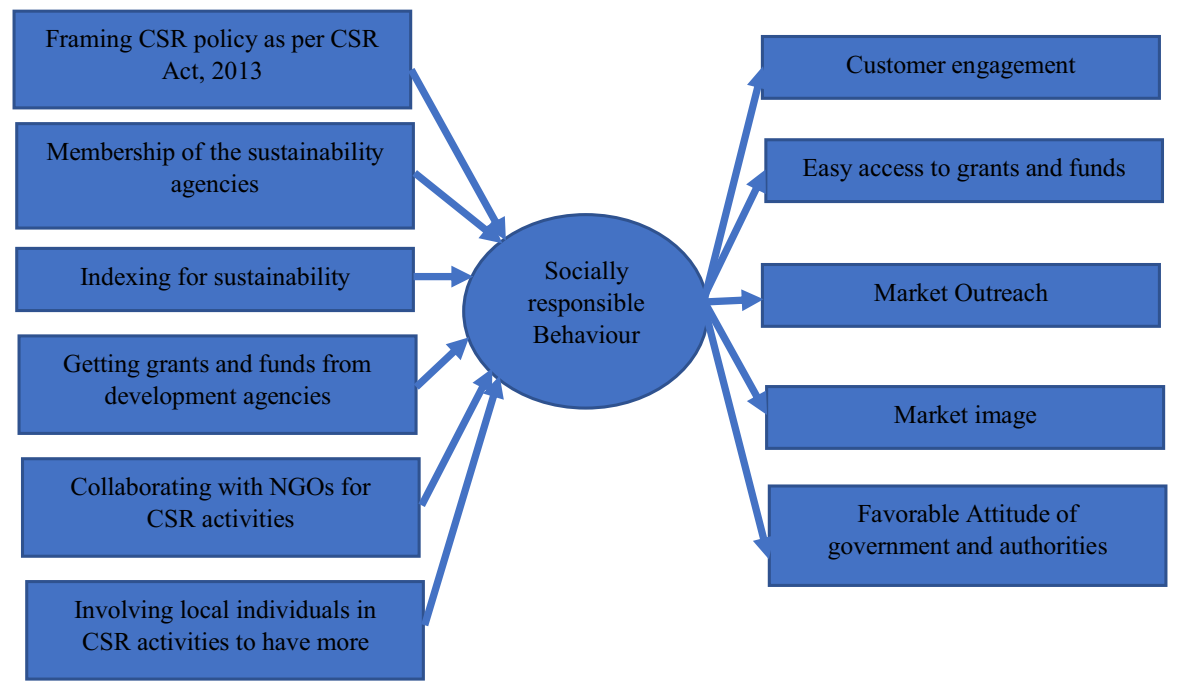

Graph 1 State-wise CSR amount spend by banks during 2014 to 2018 


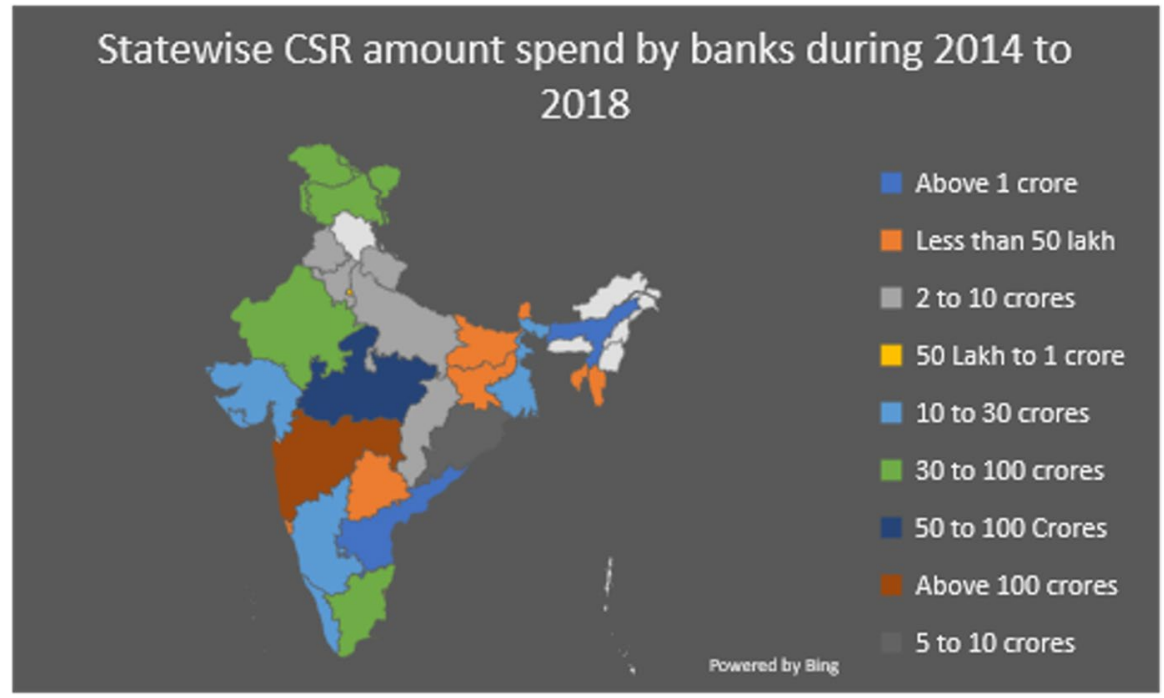

Graph 2 CSR expenses vs. GSDP growth rate

results, it was found to have a negative relation. States where banks have invested less in CSR were found to have higher growth, and states where banks have invested higher in CSR were found to have less growth rate.

Hence, from the analysis, it got clear that CSR activities of the banks have no impact on the nation's economic growth as a whole or state-wise. The reasoning behind this finding can be supported by the case analysis of YES Bank discussed by the researcher. The case analysis would unveil why the banks' CSR activities have shown no impact on economic growth and why CSR of banks is a myth nowadays.

\section{Practical implications}

The paper provides a novel contribution to the literature on the banking institutions' CSR activities. The empirical results of the research have drawn some significant implications with the assertion that the nations that promote CSR activities can attain a higher growth rate.

\section{For government and policymakers}

The role of the government is substantial for the promotion of CSR activities in the economy (Wickert et al., 2016). The study would help the policymakers and government authorities reframe the regulatory reforms, certify best practices, create multistakeholder interaction, establish a transparent monitoring mechanism to keep a check over corporate lobbying of the government, and enforce sanctions (Barth 
\& Wolff, 2009). The study will also enable the government authorities to audit the CSR expenses incurred by the various institutions in the contemporary scenario. The study's findings have ushered the way for the government to examine the gap between "de jure" and "de facto" about the expectations from the CSR of various institutions and their natural performances. The findings of the study would draw the attention of policymakers to reinventing the role of government in promoting CSR as a prominent means to boost the growth of the economy.

\section{For corporates}

The aspect of "passionate leadership" and "strategic CSR" would enable the corporates to work with a solid ethical orientation by developing ways to respond positively towards the expectations of the government and society. The study would help the corporates acquire "concentrated CSR" practice by linking them to business processes on realistic grounds, benefiting the institutions and the various stakeholders. The corporate institutions' practices would be enabled with a vision and strategy while incurring CSR expenses on some projects in the future (Petkoski \& Twose, 2003). The research would allow the corporates to acknowledge the loopholes present in their existing framework and recreate their strategies by improving efficiency and economy of operations (Durmaza et al., 2011). The study would act as a source of push factor that would drive the actions of corporates in the right direction by following the guidelines of the government and preparing their annual sustainability reports to secure the trust of multiple stakeholders as a source of futuristic opportunities.

\section{For society}

The feedback mechanism proposed in the approach would allow the external stakeholders, including the citizens, to access the information of CSR expenses incurred by the various institutions (Visser, 2009). The research findings would sensitize the individuals and investors about the institutions' actual CSR practices. The study would be beneficial for the practitioners and stakeholders, as a source to experiment with the CSR practices and their impact on the economy, society, and environment. Moreover, the non-government institutions would be persuaded to make valuable contributions, be responsible and accountable, and link with the corporate and government authorities, to act as a catalytic agent for bringing change in society, raising the level of economic growth of the nation.

Moreover, the avid readers would have the visual research concerning the CSR initiatives taken by various corporates and institutions and their effect on society, environment, and economy.

\section{Real-time case analysis (CSR and YES Bank)}

In the first part of the paper, the literature proved that various CSR activities impact the country's economic development and firm performance. But 
the interesting observation is that the economic development measures are not indicating growth. Banks are attractive in investing in CSR activities like rural developments, education and skill development, livelihood projects, and healthcare services. So, are CSR investments myth or real? YES, the bank is the classic example for this first research question. The relationship between CSR and bank performance can be seen with the YES Bank example and the answer to the vital research question raised in this study. Even after a plethora of CSR activities initiated by banks, the nation's growth rate is still lower than expected.

\section{CSR performance of YES Bank in 2014 onwards}

1. CSR policy of the bank was framed after the CSR Act came into existence in 2014-2015. As per the policy, the members of the CSR committee were three independent directors, a managing director, and one non-executive director. The CSR policy aims to promote the work in prominent spheres such as education, skill development, livelihood projects, healthcare, art and culture, and environmental sustainability.

2. YES, the bank has made CSR expenses of 15.71 crores in 2014 , which increased to 53.78 crores in 2018. The prescribed limit for the CSR expenses of the bank was 25 crores in 2014, while the actual CSR expenses were 15.71 crores. In 2015, the specified CSR expenses of the bank were 47.75 crores, while the actual CSR expenses were only 29.52 crores. In 2016, the prescribed CSR expenses were 60.02 crores, and actual CSR expenses were 41.66 crores; similarly, in 2017 and 2018, CSR expenses of the bank fell short by 32 crores and 42 crores, respectively. Here, the increasing trend of the unspent CSR amount with the bank is visible.

3. The Indian banking sector is highly competitive because of various prominent players like SBI, ICICI, and HDFC. These banks own nearly half of the Indian market. YES Bank owns nearly $3 \%$ in the market. Still, it is the only bank which got indexed in FTSE4 Good Emerging Index, Dow Jones Sustainability Index, OEKOM-Prime status (among top financial institutions out of 249 global institutions), and Vigeo Eiris (award of top 100 advanced companies from 20 emerging countries across the globe), and made its place in the Morgan Stanley Capital International Index for ESG as per ESG (environment, social, and governance) performance of banks during 2014 to 2019. These awards and recognitions seem unusual, like other private and public sector banks who were spending two or three times higher than YES Bank on CSR and had not even been recognized and awarded by similar indexes. A deep insight into these awards and recognitions clearly explains that the primary purpose of the CSR activities of the bank was not the development of the nation but fame and name on the global turf.

4. YES Bank was the only Indian bank to be included in Robeco SAM-DJSI Sustainability in 2018 for its CSR activities towards the environmental substantiality. It 
made the bank a better investment opportunity by the Robeco SAM, a specialized investment bank in sustainability investing.

5. YES Bank got the ISO certification of its 444 branches situated in metro and urban areas. It was the first Indian bank signatory of UNEP FI, Carbon Disclosure Project, Carbon Pricing Leadership Coalition, and Natural Capital Financial Alliance. The bank has also secured its place on the Climate Disclosure Leadership Index.

YES Bank's socially responsible behavior could be seen with this bank's CSR activities after implementing the CSR Act in India. CSR activities of YES Bank, as visible from the bank's website, newspapers, and published reports, have helped the bank position itself as a responsible bank at the global level. But let us deeply analyze the increasing trend of the unspent amount of CSR during the last 5 years and compare the actual CSR expenses of the bank with other private banks. One thing will clear that YES Bank has marketed its CSR activities in such a way that without spending much amount on CSR activities, it had been able to manage its position and image in the world as the best bank, a brand, which continuously worked for the environmental sustainability. The bank made its place in the top sustainability indexes of the world, for which even the oldest and largest public and private sector banks are still trying to make their places. It would be impossible without marketing CSR activities performed by YES Bank at such a mass level that it could attain a prominent position as the top development agency globally. The primary area of YES Bank, which got visible from its CSR activities, was the environment. All the major development agencies across the globe have been striving for environmental sustainability. In such a scenario, doing CSR-related activities in this area only and highlighting it continuously would have attracted the attention of top development agencies of the world towards this bank. The recognition and award segment of the bank clearly stated that the majority of the awards won by the bank were for its environment-related initiatives.

\section{CSR and financial performance of YES Bank}

1. Customer engagement: After making its place in top sustainability indexes worldwide, YES Bank was assured of getting grants from the development agencies. It then started putting its funds in addition to that grant to use it as a risk guarantee for financing the power-related projects to attract a more significant number of lenders. The higher number of lenders reduced the probability and risk on the single entity. Hence, the CSR was used for increasing the borrower's engagement and the product portfolio of the bank. YES Bank under the project "HelpAge" collaborated with the NGOs to launch its campaign Yes Respect, which was designed to target the senior citizens of the local areas of the bank branches to sell off their products and services. NGOs used to meet with the senior citizens and explain the products and services of the YES Bank, and in return, these NGOs got incentives from the bank (Ghosh, 2014). YES Bank used its CSR funds to increase its banking business instead of developing (Ghosh, 2014). Yes Bank involves the 
CSR department in client consulting borrower engagement (Business Today, 31 Jan 2014).

2. Market outreach: YES Bank has increased the branch from 630 to 1100 from 2014 to 2019 , while the number of employees increased from 9275 to 18,238 from 2014 to 2019. Total assets of the bank increased almost four times from 2014 to 2019. Due to its positive image, excessive funding, and image of a responsible corporate citizen, the bank made it possible to quickly expand its geographical area and banking operations. The growth rate of the bank showed the massive impact of the CSR activities on its growth and performance.

3. Easy access to funds and grants: The major advantage of getting indexed on the world's leading sustainability indexes, and partnership in the institutions or agencies working for sustainability, made it comparatively easier for YES Bank to get grants and easy loan access from the external agencies than other banks. This acted as a supportive factor to enhance the bank's financial performance. YES Bank regularly got grants and funding from overseas agencies to fund its CSR programs. It got funds of $150 \$$ million in 2018, the third time from the US government (OPIC), 200 \$ million from the Asian Development Bank (2014), and other foreign investment banks to develop MSMEs in India and promote women entrepreneurship.

4. The favorable attitude of regulatory bodies: Due to the CSR activities of the YES Bank, government and regulatory bodies started showing favorable interest in the bank. This could be visible in the case of YES Bank QIP. In 2016, YES Bank canceled its QIP just before the issue and was charged a very nominal amount as a penalty, and no serious action was taken against the bank. Similarly, even after having a clue about the mismanagement of funds, the founder of the YES Bank was able to successfully sell off its stake in the bank, which was possible only with the presence of a favorable attitude of the regulatory bodies towards the bank.

5. Market image: YES Bank was awarded for being excellent in sustainability. All the awards and the recognition, grants given by banks to NGOs for making short films on social change, and many other initiatives became successful. The bank mustered huge marketing due to the involvement of individuals in these CSR programs. CSR campaigns and their marketing enabled the YES Bank to positively image the bank in the market. The positive image leads to a better financial performance of the bank and having a huge customer base.

All these outcomes of the CSR activities of YES Bank proved as supporting factors for the success of the YES Bank scam. The subsequent section shows how the corporate behavior of YES Bank converted from socially responsible to socially irresponsible due to the fraud.

As per the first research question, if the banks are investing in CSR activities, it should reflect in their performance and economic development of the country. In this case, YES Bank proved that there is a relationship (Fig. 1). But still, the 
bank failed in the industry and received the response of "socially irresponsible behavior" from various stakeholders.

The second research question focuses on how banks use CSR activities as a marketing tool for better brand visibility. The following section of YES Bank explains how CSR activities are misused and various reasons for their failure.

\section{Failure of YES Bank and its socially irresponsible behavior}

The following are the significant points extracted from the study of the failure of the YES Bank, which shows the socially reckless behavior of the YES Bank towards its stakeholders.

1. The loan amount of 50,000 crores increased up to 241,000 crores from 2014 to 2019 , almost five times higher than in 2014. There is no transparent information about the beneficiaries of these loan amounts that had been disclosed in the company's annual reports. It shows that YES Bank had not fulfilled its responsibility towards its stakeholders for being transparent and trustworthy.

2. The loan amount of 50,000 crores increased up to 241,000 crores from 2014 to 2019, almost five times higher than in 2014. There is proven information about the beneficiaries of these loan amounts that had been disclosed in the company's annual reports. It shows that YES Bank had not fulfilled its responsibility towards its stakeholders for being transparent and trustworthy.

3. Contingent liability of 6.54 crores until 2019 had not been explained by the bank, which was too high compared with the YES Bank's profits that stood at around 2000 crore only. Misrepresentation of facts or not disclosing accurate information about the bank's financial performance shows irresponsible behavior on the part of YES Bank towards its stakeholders.

4. Money laundering and siphoning of funds by the founder of YES Bank of 307 crores shows the mis-utilization of the shareholders' wealth. The corporate social

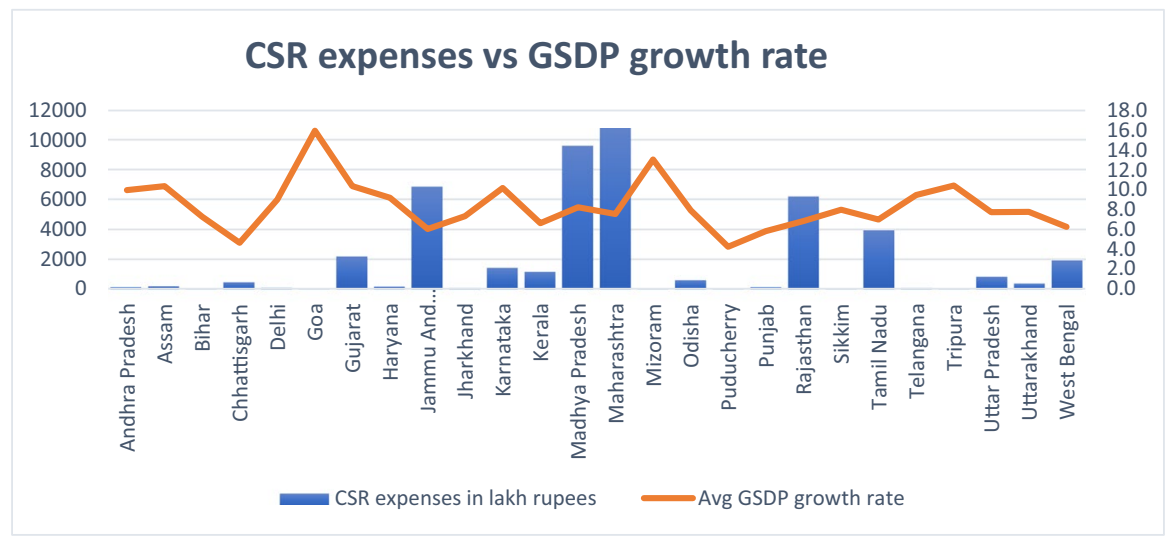

Fig. 1 Relationship between CSR and Yes Bank's performance 
responsibility of the business is to maximize the wealth of the shareholders and work in the best interest of the stakeholders.

5. Moody's revised and downgraded the credit rating of the YES Bank from "B2" to "CAA3" because of only on the day of default, resulting in a loss of 3300 crores wealth of the retail investors on the 7th March 2020. This was the result of the irresponsible behavior of the YES Bank towards its investors.

6. Resignation by an independent director of YES Bank 1 month before the YES Bank scam showed the irresponsible and insensitive behavior of the bank's top management, who were mainly responsible for maintaining and implementing the concept of corporate citizenship behavior of the bank.

7. Difficulties and pain suffered by the depositors (who are the main stakeholders of the bank) after the scam, by standing in the long queues for withdrawal of their money from banks or ATM, show how YES Bank has made rampant and callous misuse of its positive image formed in the market due to its CSR activities.

8. The end use of grants and funds received from foreign nationals or international agencies for CSR activities is also doubtful, as the bank has received vast amounts of funds for development. However, the product in the particular areas is still invisible.

YES Bank scam is a clear example of how CSR activities of the bank were misused in an unethical and socially irresponsible manner. Hence, it is clear from the case analysis of YES Bank that in India, banks are only using CSR as a marketing tool to make their image in the market, in the eyes of the regulatory bodies and society. The motive behind CSR should be the real purpose of serving the nation, the nation's people, contributing to the country's development. Still, the banks' motive for doing CSR activities is to contribute to their profit-making plans and engage in unethical practices by using the shield of CSR programs. This case analysis linked CSR and bank's performance, which has been proved by numerous researchers in the past (Gond \& Herrbach, 2006; Swarnpali \& Le, 2018; Ting, 2020), and also highlighted the fact that CSR is a myth, in the case of the Indian banking sector. Any CSR activities conducted without the real development motive can never contribute to the nation's development.

\section{Discussion and conclusion}

The study results highlight two contradictory things: A massive amount of CSR has been invested by the banks after implementing the CSR Act in India, as disclosed in their annual reports and confirmed through data available with the Ministry of Corporate Affairs, while on the other hand, even after so much investment of funds by banks in CSR activities, the country's growth rate did not improve or show any drastic shift towards growth. This is against the law of unity even where all the banks have worked in one direction due to legal obligations. However, no noticeable impact of their efforts was still visible in the nations' growth or development.

The study results will get strength by one more fact related to the huge amount of unspent CSR with the banks and corporates, which made the regulatory bodies 
amend the CSR Act and look for making corpus funds for unspent CSR. As per the Ministry of Corporate Affairs, the total amount of unspent CSR amount with the corporates in 2017 was 1574 crores, which increased to 1717 crores by 2018 . This amount is too large to be defended by the corporates why these corporates could not find the areas for investing this unspent amount of CSR. India, which is an emerging economy, is striving to achieve a remarkable growth rate by focusing on educational development of youth to increase employment, rural area development to increase the living standard of people living in these areas, and eradication of poverty by using various means, by taking funds from external agencies like the World Bank, and International Monetary Fund (IMF) even. In such a scenario, corporates are not getting ideas for investing the proposed funds for CSR activities in the country. These are entirely illogical and contradictory too. Banks have shown a massive amount of CSR in their annual reports. Their disclosure of CSR activities in yearly reports takes enormous space to attract investors and shareholders by showcasing their responsible corporate behavior. Hence, the study concluded that either the CSR expenses of banks shown in their annual reports are just a myth, as no significant relation was found between growth in CSR expenses and the economic growth of the country, or there is a lack of planning and a strategic approach followed by the banks for CSR.

Though these findings may not be applicable for the banks working in the area of CSR to give back to society, CSR is a fact, not a myth. The researcher has suggested a practical approach for those banks to make their CSR activities impactful and long-lasting for economic growth. There is a need to have a holistic ideology to ascertain the practical and realistic impacts of CSR activities performed by the banks. The banks must adopt a suitable and innovative approach to keep all their activities "SMART" i.e., sincere, moral, accountable, responsible, and transparent, to engross themselves in the feasible and specific domains to have deep-rooted, positive, and exponential outcomes for the growth of the economy.

\section{Limitations and future scope}

The findings of the study are subjected to some limitations. The data was taken only for the Indian banking sector; hence, the outcomes of the research would not be used further to draw generalizations to the other nations or other sectors of the Indian economy. Moreover, more specific data of India could have been used to bring more reliability and concrete assurance. Apart from the above-discussed parameters, the other significant indicators might have been taken into the study to bring more fruitful outcomes. CSR impacts the performance in both the short and long run. Because the CSR act started in India in 2014, and data were available for up to 2018, the impact has not been measured in the long run. It would also be more interesting to replicate the prevailing affirmations of the research work in future research. The influence of CSR expenses of institutions on economic growth requires deep study. We highly emphasize a deep inquiry into channels through which the CSR practices of the institutions could influence economic growth is necessary. Moreover, there is 
a dire need to ascertain the prominent cause of connection between the CSR efforts of the organizations or institutions with the nation's economic growth.

\section{Appendix}

\begin{tabular}{ll}
\hline S.N. & Name of bank \\
1 & City Union Bank Limited \\
2 & The Karur Vysya Bank Limited \\
3 & ICICI Bank Limited \\
4 & Yes Bank \\
5 & Canara Bank \\
6 & Allahabad Bank \\
7 & DCB Bank \\
8 & HDFC bank \\
9 & Bandhan Bank \\
10 & AU Small Finance Bank \\
11 & The South Indian Bank \\
12 & IDFC Bank \\
13 & Bhartiya Mahila Bank \\
14 & Axis Bank \\
15 & Tamilnad Mercantile Bank \\
16 & IDBI Bank \\
17 & Jammu and Kashmir Bank \\
18 & Kotak Mahindra Bank \\
19 & Nainital Bank \\
20 & Federal Bank \\
21 & IndusInd Bank \\
\hline &
\end{tabular}

\section{References}

Acemoglu, D. (2009). Introduction to modern economic growth. Princeton University Press.

Acharya, S. S. (2006). Sustainable agriculture and rural livelihoods. Agricultural Economics Research Review, 19, 205-217.

Afrin, S. (2013). Traditional vs strategic corporate social responsibility: In pursuit of supporting sustainable development. Journal of Economics and Sustainable Development, 4(20), 153-158.

Aghion, P., \& Howitt, P. W. (2009). The economics of growth. MIT Press.

Aguilera, R. V., Rupp, D. E., Williams, C. A., \& Ganapathi, J. (2007). Putting the S back in corporate social responsibility: A multilevel theory of social change in organizations. Academy of Management Review, 32(3), 836-863.

Almedia, J. A. (2002). Problematica do desenvolvimento sustentavel. In: Desenvolvimento Sustentável: necessidade e/ou posssibilidade?, Santa Cruz do Sul, p.21-29.

Anderson, R. C., Mansi, S. A., \& Reeb, D. M. (2003). Founding family ownership and the agency cost of debt. Journal of Financial Economics, 68(2), 263-285. 
Angus-Leppan, T., Metcalf, L., \& Benn, S. (2010). Leadership styles and CSR practice: An examination of sensemaking, institutional drivers and CSR leadership. Journal of Business Ethics, 93(2), $189-213$.

Arendt, S., \& Brettel, M. (2010). Understanding the influence of CSR on corporate identity, image, and firm performance. Management Decision, 48(10), 1469-1492.

Balmer, J., \& Greyser, S. (2006). Corporate marketing - Integrating corporate identity, corporate branding, corporate communications, corporate image and corporate reputation. European Journal of Marketing, 40(7\&8), 730-741. https://doi.org/10.1108/03090560610669964

Baron, D. P. (2007). Corporate social responsibility and social entrepreneurship. Journal of Economics and Management Strategy, 5(3), 683-717.

Barro, R. J., \& Sala-I-Martin, X. (2004). Economic Growth. Massachusetts, MIT Press.

Barth, R., \& Wolff, F. (2009). Corporate social responsibility in Europe: Rhetoric and realities. Edward Elgar Publishing.

Behnam, M., \& MacLean, T. L. (2011). Where is the accountability in international accountability standards? A decoupling perspective. Business Ethics Quarterly, 21(1), 45-72.

Belasri, S., Gomes, M., \& Pijourlet, G. (2020). Corporate social responsibility and bank efficiency. Journal of Multinational Financial Management, 54(March), 1-10. https://doi.org/10.1016/j.mulfin. 2020.100612

Bhattacharyya, A. \& Rahman, Md L. (2019). Mandatory CSR expenditure and firm performance. Journal of Contemporary Accounting \& Economics, 15(3), 100163.

Bihari, S. C., \& Pradhan, S. (2011). CSR and performance: The story of banks in India. Journal of Transnational Management, 16(1), 20-35.

Brammer, S., \& Millington, A. (2005). Corporate reputation and philanthropy: An empirical analysis. Journal of Business Ethics, 61(4), 29-44.

Business Today (2020). Now, India Inc can spend CSR funds to combat coronavirus, Retrieved 14 April, 2020, from https://www.businesstoday.in/latest/corporate/story/now-indian-inc-can-spend-csrfunds-to-combat-coronavirus-252786-2020-03-23

Campbell, J. L. (2007). Why would corporations behave in sociallyresponsible ways? 32(3), 946-967.

Carrin, M. (2007). In K. K. Misra \& J. H. Lowry (Eds.), Women adivasis-subalterns perspectives on the empowerment of santal women: Recent studies on India women. Rawat Publications.

Chen, Y. C., Mingyi, H., \& Wang, Y. (2018). The effect of mandatory CSR disclosure on firm profitability and social externalities: Evidence from China. Journal of Accounting and economics, 65(4), 169-190.

Cho, C. H., Roberts, R. W., \& Patten, D. M. (2010). The language of US corporate environmental disclosure. Accounting Organization of Sociology, 35(4), 431-443.

Cho, S. Y., Lee, C., \& Pfeier, R. J. (2013). Corporate social responsibility performance and information asymmetry. Journal of Accounting and Public Policy, 32(1), 71-83.

Chong, M. (2009). Employee participation in CSR and corporate identity: Insights from a disasterresponse program in the Asia-Pacific. Corporate Reputation Review, 12(2), 106-119.

Davies, B., \& Brighouse, T. (2010). Passionate leadership. Management in Education, 24(1), 4-6.

De La Croix, D., \& Michel, P. (2008). A theory of economic growth. Cambridge University Press.

Decker, O. S. (2004). Corporate social responsibility and structural change in financial services. Managerial Auditing Journal, 19(6), 712-728.

Deegan, C. (2000). The legitimising effect of social and environmental disclosures - A theoretical foundation. Accounting, Auditing and Accountability Journal, 15(3), 282-312.

Delmas, M., \& Burbano, V. (2011). The drivers of greenwashing. California Management Review, 54(1), 64-87.

Dillard, J., \& Vinnari, E. (2018). Critical dialogical accountability: from accounting-based accountability to accountability-based accounting. Critical Perspectives on Accounting, 62, 16-38.

Dobers, P., \& Halme, M. (2009). Corporate social responsibility and environmental management. Business and Society Review, 16(5), 237-249.

Du, S., Bhattacharya, C. B., \& Sen, S. (2010). Maximizing business returns to corporate social responsibility (CSR): The role of CSR communication. International Journal of Management Reviews, 12(1), 8-19.

Durmaza, V., Ates, S. S., \& Duman, G. (2011). CSR as a tool to cope with economic crises: The case of TEI. Procedia Social and Behavioral Sciences, 24, 1418-1426. 
Fatma, M., \& Rahman, Z. (2014). Building corporate identity using corporate social responsibility: A website study of Indian banks. Social Responsibility Journal, 10(4), 591-601. https://doi.org/10. 1108/SRJ-01-2013-0002

Fontaine, M. (2013). Corporate social responsibility and sustainability: The new bottom line? International Journal of Business and Social Science, 4(4), 110-119.

Gallardo, G. (2009). Statistics, knowledge and policy: Charting progress, Building Visions, Improving Life. The $3^{\text {rd }}$ OECD World Forum. Busan, Korea 27-30 October, 1-13.

Gallup. (2013). State of the global workplace: Employee engagement insights for business leaders worldwide (pp. 34-45). Gallup.

Garriga, E. M., \& Meie, D. (2004). Corporate social responsibility theories: Mapping the territory. Journal of Business Ethics, 53(2), 51-71.

Georgiadou, E. and Nickerson, C. (2021). Marketing strategies in communicating CSR in the Muslim market of the United Arab Emirates: Insights from the banking sector, Journal of Islamic Marketing, Advance online publication. https://doi.org/10.1108/JIMA-09-2020-0274

Ghosh, S. (2014). Yes Bank involves CSR department in client consulting, borrower engagement, Business Today. Retrived December 7, 2021, from https://www.businesstoday.in/industry/banks/story/ yes-bank-involves-csr-department-in-client-consulting-borrower-engagement-134439-2014-01-31

Gill, S. (2007). Corporate social responsibility: Issues and implementation in APO member countries, Retrieved 12 July 2021, from www.apo-tokyo.org/rr_papers/rr2007_11_07.pdf

Glavas, A. (2016). Corporate social responsibility and employee engagement: Enabling employees to employ of their whole selves at work. Frontiers in Psychology, 7(February), 1-34. https://doi.org/ $10.3389 /$ fpsyg.2016.00796

Gond, J. P., \& Herrbach, O. (2006). Social reporting as an organizational learning tool? A theoretical framework. Journal of Business Ethics, 65(4), 359-371.

Guiral, A. (2012). Corporate social performance, innovation intensity and financial performance: Evidence from lending decisions. Behavioural Research in Accounting, 24(2), 65-85.

Hancock, J., \& Bauman, P. (2012). Stocktaking in livelihood projects in India: A synthesis paper. Food and Agriculture Organization of United Nations, 3, 1-37.

Hartanto, W., Islami, N. N., Mardiyana, L. O., Ikshan, F. A., \& Rizal, A. (2019). Analysis of Human Development Index in East Java Province Indonesia. Earth and Environmental Sciences, 243(1), $1-7$.

Heal, G. (2005). Corporate social responsibility: An economic and financial framework. Geneva Pap Risk Insurer Issues, 30(3), 387-409.

Hohnen, P., \& Potts, J. (2007). Corporate social responsibility: An implementation guide for business. International Institute of Sustainable Development.

Howell, E., Kingley, T., \& Etangio, M. (2003). Using the national neighbourhood indicators partnerships to improve public health. Journal of Public Health Management and Practice, 9(3), 235-242.

Hulin, C. L. (2014). Work and being: The meanings of work in contemporary society. In J. K. Ford, J. R. Hollenbeck, \& A. M. Ryan (Eds.), The nature of work: Advances in psychological theory, methods, and practice (pp. 9-33). American Psychological Association. https://doi.org/10.1037/14259-002

Isonel, S. M., Chaicouski, A., \& Meneguzzo, P. M. (2009). Problem of sustainable development: Challenges to its implementation and the possibility of minimization of socio-environmental problems. Electronic Journal of the Masters in Environmental Education, 22(1), 509-520.

Jamali, D., \& Mirshak, R. (2007). Corporate social responsibility (CSR): Theory and practice in a developing country context. Journal of Business Ethics, 72(3), 243-262.

Jo, H., \& Harjoto, M. (2012). The causal effect of corporate governance on corporate social responsibility. Journal of Business Ethics, 106(1), 53-72.

Juscius, V. (2007). Corporate social responsibility and sustainable development: Management of organizations. Systematic Research, 44, 35-44.

Kao, E. H., Yeh, C. C., Wang, L. H., \& Fung, H. G. (2018). The relationship between CSR and performance: Evidence in China. Pacific-Basin Finance Journal, 51(October), 155-170.

Kashyap, M., \& Choudhury, N. (2014). Media content freedom and democracy. Kanishka Publishers.

Khan, H. Z. (2016). Multi-dimensional performance measurement practices in developing countries: A literature review and future research direction. Corporate Governance and Control, 13(2), 497-517.

Khan, H., Islam, M., Fatima, J., \& Ahmed, K. (2011). Corporate sustainability of major commercial banks in line with GRI: Bangladesh evidence. Social Responsibility Journal, 7(3), 347-362. 
Khan, A., Muttakin, M. B., \& Siddiqui, J. (2013). Corporate governance and corporate social responsibility disclosures: Evidence from an emerging economy. Journal of Business Ethics, 114(2), 207-223.

Khan, H., Ali, M., \& Fatima, J. K. (2014). Determinants and recent development of sustainability reporting of banks in developing countries: The case of Bangladesh. Corporate Ownership and Control, 11(4), 507-519.

Khandelwal, R., \& Swarna, B. (2014). The new CSR regulation in India: The way forward. Procedia Economics and Finance, 11, 60-67.

Khojastehpour, M., \& Riad, S. S. M. (2019). Addressing the complexity of stakeholder management in international ecological setting: A CSR approach. Journal of Business Research. https://doi.org/10. 1016/j.jbusres.2019.05.012

Lankoski, L. (2009). Differential economic impacts of corporate responsibility issues. Business and Society, 48(2), 206-224.

Lee-Davis, L. (2017). Ethical CSR leadership: Passion or fashion. The Journal of Sustainable Entrepreneurship and Corporate Social Responsibility, 2(2), 1-22.

Lim, J. S., \& Greenwood, C. A. (2017). Communicating corporate social responsibility (CSR): Stakeholder responsiveness and engagement strategy to achieve CSR goals. Public Relations Review, 34, 768-776. https://doi.org/10.1016/j.pubrev.2017.06.007

Lyon, T., \& Montgomery, A. (2015). The means and end of greenwashing. Organization Environment, 28(2), 223-249. https://doi.org/10.1186/s40991-019-0044-9

Macmillan, J. R., Huddleston, T., Woodley, M., \& Fothergill, K. (2003). Best management practice development to minimize environmental impact from large flow-through trout farms. Aquaculture, 226, 91-99.

Mahapatra, B., \& Mohanty, V. (2013). Corporate social responsibility is the key for environmental and social sustainability. Public Administration Review, 2(4), 1-17.

Maignan, I., \& Ferrell, O. C. (2000). Measuring corporate citizenship in two countries: The case of United States and France. Journal of Business Ethics, 23(3), 283-297.

Manescu, C. (2011). Stock returns in relation to environmental, social and governance performance: Mispricing or compensation for risk? Sustainable Development, 19(2), 95-118.

Mansoor, K. (2016). CSR standards and Islamic banking practice. The Journal of Development areas, 50(5), 295-306.

Margolis, J. D., \& Walsch, J. P. (2003). Misery loves company: Rethinking social initiatives by business. Administrative Science Quarterly, 25(2), 268-305. https://doi.org/10.2307/3556659

Marin, L., Ruiz, S., \& Rubio, A. (2009). The role of identity salience in the effects of corporate social responsibility on consumer behavior. Journal of Business Ethics, 84(1), 65-78. https://doi.org/10. 1007/s10551-008-9673-8

Maxwell, J. W., Lyon, T. P., \& Hackett, S. C. (2000). Self-regulation and social welfare: The political economy of corporate environmentalism. Journal of Law and Economics, 43(2), 583-618.

McGrath, S. (2011). Vocational education and training for development: A policy in need of a theory? International Journal of Educational Development, 32(5), 1-21.

McGuire, J. B., Sundgren, A., \& Schneeweis, T. (1988). Corporate social responsibility and firm financial performance. Academy of Management Journal, 31(4), 854-872.

Mcwilliams, A., \& Siegel, D. (2001). Corporate social responsibility: A theory of the firm perspective. The Academy of Management Review, 26(1), 117-127.

Mensah, A. M., \& Castro, L. C. (2004). Sustainable resource use \& sustainable development: A contradiction. Retrieved from December 9, 2021, from https://www.zef.de/fileadmin/downloads/forum/ docprog/Termpapers/2004_3b_Mensah_Castro.pdf

Mishra, S., \& Modi, S. B. (2012). Positive and negative corporate social responsibility, financial leverage, and idiosyncratic risk. Journal of Business Ethics., 117(2), 431-448.

Mittal, I., \& Gupta, K. R. (2015). Natural resources depletion and economic growth in the present era. SOCH-Mastnath Journal of Science \& Technology, 10(2), 24-28.

Moravcikova, K., Stefanikova, L., \& Rypakova, M. (2015). CSR reporting as an important tool of CSR communication. Procedia Economics and Finance, 26, 332-338.

Navarro Espigares, J. L., and Lopez, J. M. Gonzalez (2006). Corporate social responsibility and economic growth, Estudios de Economía Aplicada , 24 (2), 723-749.

Netar, T. (2017). Impact of institutions on rural livelihoods case study of Village Mundoti, Retrieved April 19, 2020 from https://mpra.ub.uni-muenchen.de/87287/2/MPRA_paper_87287.pdf

Newell, P. (2005). Citizenship, accountability and community: The limits of CSR agenda. International Affairs, 81(3), 541-557. https://doi.org/10.1111/j.1468-2346.2005.00468.x 
Nielsen, M. E. (2005). The politics of corporate social responsibility and child labour in Bangladeshi garment industry. International Affairs, 81(3), 559-580. https://doi.org/10.1111/j.1468-2346.2005. 00469.x

Onishi, A. (2007). The impact of CO2 emissions on the world economy: Policy simulations of FUGI global model. Journal of Policy Modeling, 29(6), 797-819. https://doi.org/10.1016/j.jpolmod.2007. 07.007

Pedrero, A. M., Garcia, F. J. C., \& Castillo, D. J. (2019). The relationship between social responsibility and business performance: An analysis of the agri-food sector of Southeast Spain. Sustainability, 11(22), 1-23. https://doi.org/10.3390/su11226390

Perez, A., \& del Bosque, I. R. (2012). The role of CSR in the corporate identity of banking service providers. Journal of Business Ethics., 108(2), 145-166. https://doi.org/10.1007/s10551-011-1067-7

Perez, A., de los Salmones, M. M. G., \& del Bosque, I. R. (2013). The effect of corporate association on consumer behavior. European Journal of Marketing, 47(1/2), 218-238.

Perrini, F., Russo, A., Tencati, A., \& Vurro, C. (2011). Deconstructing the relationship between corporate social and financial performance. Journal of Business Ethics, 102(1), 59-76.

Petkoski, D., and N. Twose, (2003). Public policy for corporate social responsibility, WBI Series on Corporate Responsibility, July, 7-25.

Pieter, B. (2010). The impact of human capital development on economic growth. Economics Studies, $55(1), 21-40$.

PNDA Guidelines. (2015). Employment, livelihood and social protection: Volume B, GFDRR (pp. 1-39). World Bank Group.

Poolthong, Y., \& Mandhachitara, R. (2009). Consumer expectations of CSR, perceived service quality and brand effect in Thai retail banking. International Journal of Bank Marketing, 27(7), 408-427.

Porter, M., \& Kramer, M. (2006). Strategy and society: The link between competitive advantage and corporate social responsibility. Harvard Business Review, 84(December), 78-92.

Ramasamy, B., \& Ting, H. W. (2004). A Comparative Analysis of Corporate Social Responsibility Awareness: Malaysian and Singaporean Firms. The Journal of Corporate Citizenship, 13, 109-123.

Reinhardt, F., Stavins, R., \& Vietor, R. (2008). Corporate social responsibility through an economic lens, NBER Working Paper Series (Vol. 13989, pp. 1-36). National Bureau of Economic Research.

Sen, R. (2017). Corporate social responsibility with socio-economic development. International Journal of Management, IT and Engineering, 7(6), 119-124.

Shapiro, B., \& Matson, D. (2008). Strategies of resistance to internal control regulation Accounting. Organizations and Society, 33(3), 199-228.

Sharma, S. (2011). Corporate social responsibility in India. Indian Journal of Industrial Relation, 46(4), 637-649.

Siegel, D. S., \& Vitaliano, D. F. (2007). An empirical analysis of the strategic use of corporate social responsibility. Journal of Economics and Management Strategy, 16(3), 773-792.

Skare, M., \& Golja, T. (2014). The impact of government CSR supporting policies on economic growth. Journal of Policy Modeling, 36(3), 562-577.

Spencer, B., \& Taylor, G. (1987). A within and between analysis of the relationship between corporate social responsibility and financial performance. Akron Business and Economic Review, 18(1), 7-18.

Belal, R. And Momin H. (2009). Corporate social reporting (CSR) in emerging economies: A review and future direction, First South American Congress on Social and Environmental Accounting Research - Brazil, 27-28 July, CSEAR 2009, Federal University of Rio de Janeiro, 1-33.

Swarnpali, R. M., \& Le, L. (2018). Corporate sustainability reporting and firm value: Evidence from a developing country. International Journal of Organization Innovation, 10(4), 69-78.

Szczuka, M. (2015). Social dimension of sustainability in CSR standards. Procedia Manufacturing, 3, 4800-4807. https://doi.org/10.1016/j.promfg.2015.07.587

Tai-kei, A., \& Coates, P. (2002). Citizen participation: Legitimizing performance measurement as a decision tool. Government Finance Review, 10(April), 19-34.

Tang, Z., Hull, C. E., \& Rothenberg, S. (2012). How corporate social responsibility engagement strategy moderates the CSR-financial performance relationship. Journal of Management Studies, 49(1), 1274-1130.

Telli, C., Voyvoda, E., \& Yeldan, E. (2008). Economics of environmental policy in Turkey: A general equilibrium investigation of the economic evaluation of sectoral emission reduction policies for climate change. Journal of Policy Modeling, 30(2), 321-340. 
Tilton, J. (2003). Civilization and the threat of mineral depletion report. Minerals and Energy-Raw Materials Report, 18(1), 33-42.

Ting, P.-H. (2020). Do large firms just talk corporate social responsibility? - The evidence from CSR report disclosure. Finance Research Letters, 38(4), 101476.

Truscott, R. A., Bartlett, J. L., \& Tywoniak, S. A. (2009). The reputation of the corporate social responsibility industry in Australia. Australasian Marketing Journal, 17(2), 84-91.

Turker, D. (2009). Measuring corporate social responsibility: A scale development study. Journal of Business Ethics, 85(4), 411-427.

Uddin, S., Siddiqui, J., \& Islam, M. A. (2016). Corporate social responsibility disclosures, traditionalism and politics: A story from a traditional setting. Journal of Business Ethics, 151(2), 409-428.

Valor, C. (2005). Corporate social responsibility and corporate citizenship: Towards corporate accountability. Business and Society Review, 110(2), 191-212.

Vastradmath, N. (2015). The role of corporate social responsibility for an inclusive growth in the society. The practice of CSR in the context of rural development in India. International Journal of Scientific and Research Publications, 5(10), 1-5.

Verma, S., \& Chauhan, R. (2007). Role of CSR in developing nations. International Marketing Conference on Marketing and Society, 10(April), 139-146.

Vilanova, M., Lozano, J. M., \& Arenas, D. (2009). Exploring the nature of the relationship between CSR and competitiveness. Journal of Business Ethics, 87(1), 57-69.

Visser, Wayne (2009). Corporate social responsibility in developing countries: In CSR in global context, Routledge

Waddock, S. A., \& Graves, S. B. (1997). The corporate social performance-financial performance link. Strategic Management Journal, 18(4), 303-319.

Wagner, M. (2010). Corporate social performance and innovation with high social benefits: A quantitative analysis. Journal of Business Ethics, 94(4), 581-591.

Ward, H., Fox, T., Wilson, E. and Zarsky, L., (2007). CSR and developing countries what scope for government action? Retrieved April 29, 2020,from https://pubs.iied.org/pdfs/G02247.pdf.

Wensen, K., Van Broer, W., Klein and J. Knoof (2011). The study of play in sustainability reporting in the European Union, Retrieved June 29, 2020, from https://www.somo.nl/wp-content/uploads/2011/ 04/The-State-of-Play-in-Sustainability-Reporting-in-the-European-Union.pdf

Werner, W. (2009). Corporate social responsibility initiatives addressing social exclusion in Bangladesh. Journal of Health, Population and Nutrition, 27(4), 545-562.

Whitehouse, L. (2006). Corporate social responsibility: Views fromthe frontline. Journal of Business Ethics, 63(3), 279-296.

Wickert, C., Scherer, A. G., \& Spence, L. J. (2016). Walking and talking corporate social responsibility: Implications of Rm size and organizational cost. Journal of Management Studies, 53(7), 1169-1196.

Wong, C. Y., Boon-itt, S., \& Wong, C. W. Y. (2011). The contingency effects of environmental uncertainty on the relationship between supply chain integration and operational performance. Journal of Operations Management, 29(6), 604-615.

Yuan, W., Bao, Y., \& Verbeke, A. (2011). Integrating CSR initiatives in business: An organizing framework. Journal of Business Ethics, 101(1), 75-92.

Zhang, D., Morse, S., \& Ma, Q. (2019). Corporate social responsibility and sustainable development in China: Current status and future perspectives. Sustainability, 11(16), 1-23.

Publisher's note Springer Nature remains neutral with regard to jurisdictional claims in published maps and institutional affiliations. 